\title{
SOEP
}

SOEPpapers

on Multidisciplinary Panel Data Research
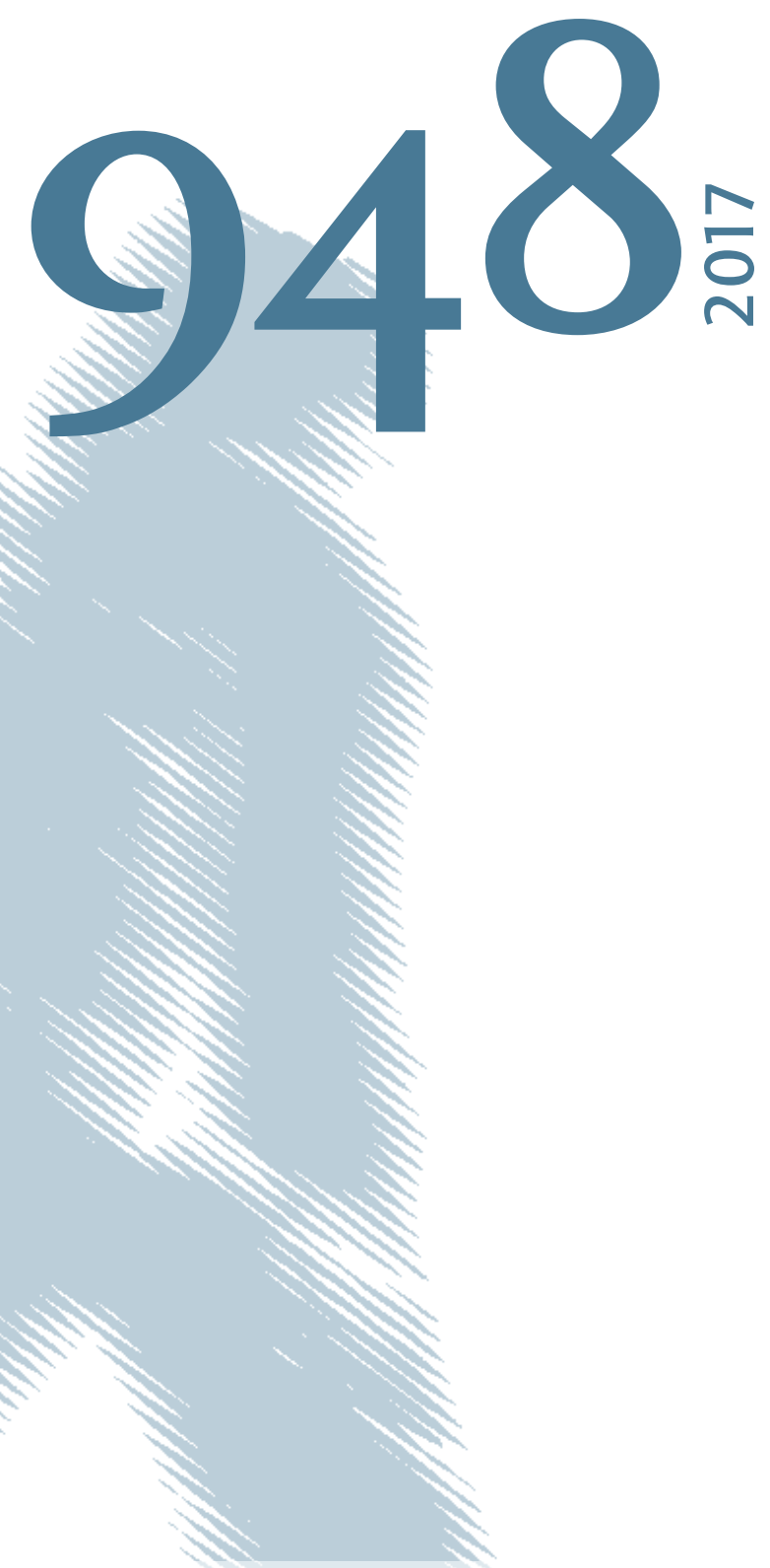

\section{The Short-Term Distributional Effects of the German Minimum Wage Reform}


This series presents research findings based either directly on data from the German SocioEconomic Panel study (SOEP) or using SOEP data as part of an internationally comparable data set (e.g. CNEF, ECHP, LIS, LWS, CHER/PACO). SOEP is a truly multidisciplinary household panel study covering a wide range of social and behavioral sciences: economics, sociology, psychology, survey methodology, econometrics and applied statistics, educational science, political science, public health, behavioral genetics, demography, geography, and sport science.

The decision to publish a submission in SOEPpapers is made by a board of editors chosen by the DIW Berlin to represent the wide range of disciplines covered by SOEP. There is no external referee process and papers are either accepted or rejected without revision. Papers appear in this series as works in progress and may also appear elsewhere. They often represent preliminary studies and are circulated to encourage discussion. Citation of such a paper should account for its provisional character. A revised version may be requested from the author directly.

Any opinions expressed in this series are those of the author(s) and not those of DIW Berlin. Research disseminated by DIW Berlin may include views on public policy issues, but the institute itself takes no institutional policy positions.

The SOEPpapers are available at http://www.diw.de/soeppapers

\section{Editors:}

Jan Goebel (Spatial Economics)

Martin Kroh (Political Science, Survey Methodology)

Carsten Schröder (Public Economics)

Jürgen Schupp (Sociology)

Conchita D'Ambrosio (Public Economics, DIW Research Fellow)

Denis Gerstorf (Psychology, DIW Research Director)

Elke Holst (Gender Studies, DIW Research Director)

Frauke Kreuter (Survey Methodology, DIW Research Fellow)

Frieder R. Lang (Psychology, DIW Research Fellow)

Jörg-Peter Schräpler (Survey Methodology, DIW Research Fellow)

Thomas Siedler (Empirical Economics, DIW Research Fellow)

C. Katharina Spieß (Education and Family Economics)

Gert G. Wagner (Social Sciences)

ISSN: 1864-6689 (online)

German Socio-Economic Panel (SOEP)

DIW Berlin

Mohrenstrasse 58

10117 Berlin, Germany

Contact: soeppapers@diw.de

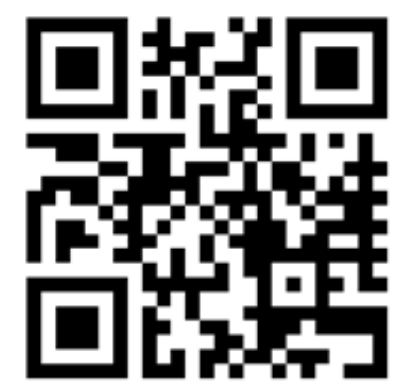




\title{
The Short-Term Distributional Effects of the German Minimum Wage Reform
}

\author{
Marco Caliendo* \\ Alexandra Fedorets ${ }^{\dagger}$ \\ Malte Preuss ${ }^{\ddagger}$ \\ Carsten Schröder ${ }^{\S}$ \\ Linda Wittbrodt \\ Working Paper
}

\begin{abstract}
This study quantifies the short-term distributional effects of the new statutory minimum wage in Germany. Using detailed survey data (German Socio-Economic Panel), we assess changes in the distributions of hourly wages, contractual and actual working hours, and monthly earnings. Our descriptive results indicate growth at the bottom of the hourly wage distribution in the post-reform year, but also considerable noncompliance among eligible employees. In a second step, we employ a difference-in-differences analysis and exploit regional variation in the "bite" of the intervention, measured by the share of employees in a geographical region with wages below the minimum wage prior to the reform. We document the reform's positive effect at the bottom of the wage distribution. However, we find a negative effect of the reform on contractual hours worked, which explains why there is no effect on monthly earnings. Given that actual hours worked decrease less than contractual hours, our evidence suggests an increase in unpaid overtime.
\end{abstract}

Keywords: minimum wage, wage distribution, hourly wages, inequality

JEL codes: J31, J38, J22

\footnotetext{
*University of Potsdam, IZA, DIW, IAB, e-mail: caliendo@uni-potsdam.de.

${ }^{\dagger}$ SOEP at DIW Berlin, e-mail: afedorets@diw.de Corresponding address: DIW Berlin - German Institute for Economic Research, Mohrenstr. 58, 10117 Berlin, Germany. Tel: +49 3089789 321, Fax: +49 3089789115.

${ }^{\ddagger}$ Free University Berlin, e-mail: malte.preuss@fu-berlin.de

${ }^{\S}$ SOEP at DIW and Free University Berlin, Department of Economics, e-mail: cschroeder@diw.de

๑ University of Potsdam, e-mail: wittbrodt@empwifo.uni-potsdam.de

We are grateful for financial support from the Leibniz Association under the research project "Evaluating the Minimum Wage Introduction in Germany (EVA-MIN) - Innovative Knowledge Transfer and Evidence-Based Evaluation."

The authors thank Steven Durlauf, Ingo Isphording, Jeffrey Wooldridge, as well as participants of the annual conferences of ESPE (Glasgow, 2017), the Society for the Study of Economic Inequality (ECINEQ, New York City, 2017), EEA (Lisbon, 2017), Verein für Socialpolitik (Vienna, 2017), and EALE (St. Gallen, 2017) for their feedback. The Stata code used in the preparation of this paper are available on request from Alexandra Fedorets at the SOEP Department at DIW Berlin, 10117 Berlin, Germany.
} 


\section{Introduction}

Since the early 1990s, earnings inequality in Germany has been rising. Most notably, real wages of workers in the lower part of the distribution have stagnated or decreased. Key reasons for these developments include globalization and skill-biased technological change, de-unionization, and deregulation of the German labor market. ${ }^{1}$ In response, on January 1, 2015, German policy makers enacted a statutory gross minimum wage of $€ 8.50$ per hour. It was a major intervention into the labor market, given the very limited legal exemptions and considerable "bite" of the reform: in the year before its implementation, around 10 to 14 percent of eligible employees earned less than $€ 8.50$ per hour. ${ }^{2}$

Prior to the minimum wage reform's implementation, experts in Germany fiercely debated its potential effects. While supporters stressed positive distributional effects and fairness, opponents warned of the reform's economic costs. Their argument was that the reform would reduce Germany's international competitiveness, destroying jobs in the low-wage segment in particular. For example, Knabe et al. (2014) estimated a loss of about 340,000 full-time equivalent jobs in the long run. However, the short-term empirical evidence does not support such negative predictions. Using administrative data on regional employment and firm data, Garloff (2016), Bossler and Gerner (2016), and Caliendo et al. (2017) find no or only small negative short-run employment effects. Rather, there is evidence that the reform led to the phenomenon of "mini-jobs"3 being transformed into regular employment.

Previous research offers several possible explanations for the absence of negative employment effects (Card, 1992a; Card and Krueger, 1992; Dube et al., 2010). First, labor markets are better described by monopsonistic than by perfect competition. Under monopsonistic competition, it is unclear what employment effects a minimum wage will have (see Manning, 2003). Second, legal and intra-firm administrative hurdles may delay layoffs, meaning that the negative employment effects will be larger in the medium and long term (see, e.g., reports providing evidence to this effect from the US, Neumark et al., 2004). Third, employers might ignore new minimum wage regulations and might not adapt wages accordingly. Noncompliance may thus prevent the

\footnotetext{
${ }^{1}$ See Antonczyk et al. (2010); Bach et al. (2009); Baumgarten et al. (2013); Dustmann et al. (2009); Card et al. (2013); Corneo (2015).

${ }^{2}$ To calculate the scope of the reform, see Amlinger et al. (2016); Brenke (2014); Falck et al. (2013); Kalina and Weinkopf (2014); Lesch et al. (2014). Germany ranks around the middle of OECD countries in terms of the scope of the minimum wage reform (see OECD, 2015). In Section 2, we discuss the institutional background and the exempted groups in more detail.

${ }^{3}$ Mini-jobs or marginal employment are a specific type of job in Germany with a fixed pay of $€ 450$ per month and no compulsory social security contributions by employees (see, e.g., Caliendo et al., 2016, for more details).
} 
minimum wage from exerting its full impact on labor costs and thus on employment (Brown, 1999; Metcalf, 2008; Mindestlohnkommission, 2016a).

In the present paper, we provide the first in-depth analysis of the reform's distributional effects on wages, earnings, and working hours. Thus, it complements existing evidence on the employment effects of the minimum wage reform by analyzing the reform's primary effects. Our analysis is based on data from the German Socio-Economic Panel (SOEP). The hourly wage is the focal point of the reform, and with the SOEP, we can distinguish two wage concepts: an hourly wage based on contractual working hours and an hourly wage based on actual hours worked. The contractual wage is set out in black and white in employment contracts, while the actual wage reflects the effective workload of the employed person - a common blind spot in administrative data. Our analysis of working hours sheds light on another potential adjustment mechanism to the reform in addition to layoffs. Finally, with the analysis of monthly earnings, we examine whether the reform has succeeded in improving the earnings situation of low-wage employees, one of its stated aims.

Methodologically, our analysis uses descriptive tools borrowed from the literature on economic inequalities and poverty, as well as a difference-in-differences regression framework (DiD) with continuous treatment (Card, 1992b; Caliendo et al., 2017). Descriptively, we provide graphical representations of hourly wage distributions before and after the reform, and we also assess wage inequalities among low-wage employees and quantify their wages relative to the minimum wage. The DiD framework builds on regional variation in treatment intensity, measured by the share of eligible employees in a region paid below the minimum wage in a pre-reform period. While the statutory minimum wage is fixed at the level of $€ 8.50$ in all German regions, the wage structure exhibits significant regional differences. Prior to the reform, the regional shares of employed people earning less than $€ 8.50$ per hour by contract varied considerably. According to our data for 2013, for instance, the bite ranges from 5.2 to 39.4 percent across Germany's Raumordnungsregionen (ROR, or planning regions), and is 15.6 percent on average.

The results of our analyses can be summarized as follows. The descriptive evidence indicates a positive effect of the reform on hourly wages. In the post-reform period, both actual and contractual wages in the bottom wage segment increased at an above-average rate. At the same time, a considerable share of eligible employees, about seven percent, earned less than the minimum wage, but the average gap between their wages and the minimum wage threshold of $€ 8.50$ became smaller. With respect to monthly earnings, our data show that the increase 
in hourly wages in the bottom wage segment does not translate into higher monthly earnings. This is because the wage increase at the bottom is accompanied by an almost proportionate reduction in the hours worked. The DiD analysis confirms the reform's positive effect on wages at the bottom of the hourly wage distribution, the negative effect on working hours, and the non-existent effect on earnings. One potential explanation for the small short-term employment effects is noncompliance. In the short term, the minimum wage reform increased labor costs less than expected, putting less pressure on firms to lay off employees.

The paper proceeds as follows. Section 2 gives an overview of the institutional details of the reform. Section 3 reviews the literature on distributional effects of minimum wages. Section 4 introduces the data used in the empirical analyses. Section 5 provides results of the descriptive before-after analysis for gross hourly wages, monthly earnings, and hours worked. Section 6 introduces the identification strategy, discusses its validity, and provides results for hourly wages, monthly earnings, and hours worked. In Section 7, we provide various sensitivity tests. Section 8 concludes.

\section{Institutional background}

On January 1, 2015, a general statutory minimum wage of $€ 8.50$ per hour became effective in Germany. It is codified in the Minimum Wage Law. ${ }^{4}$ Before its introduction, there were only sector-specific wage floors set by collective agreements. Sector-specific minimum wages had been introduced over the last two decades in several sectors including construction and roofing (in 1997), hairdressing (in 2013) and security services (in 2011). ${ }^{5}$ In the following, we focus on the regulations pertaining to the statutory minimum wage.

With the introduction of the Minimum Wage Law, the German Minimum Wage Commission also recommended future adjustments of the minimum wage level. In light of the negligible employment effects in the first year after the reform, the minimum wage was raised by $€ 0.34$ per hour effective January 1, 2017 (see Mindestlohnkommission, 2016b).

Coverage and level. As of January 2015, almost all employees in Germany were eligible for the statutory gross minimum wage of €8.50. During a transitional period ending in January 2017,

\footnotetext{
${ }^{4}$ MiLoG, https://www.gesetze-im-internet.de/milog/, last accessed on December 14, 2017.

${ }^{5}$ Most sector-specific minimum wages are higher than the statutory minimum wage and were increased after the minimum wage reform (Amlinger et al., 2016). An overview of sector-specific minimum wages is given in Schröder (2014), while König and Möller (2009), Frings (2013), and vom Berge et al. (2013) investigate their economic effects.
} 
exemptions applied to some sectors with pre-existing sector-specific minimum wages. Permanent exemptions apply to minors (persons below the age of 18) and trainees and interns (e.g., students or apprentices completing required or elective internships of up to three months). Unemployed people who have been registered as such for at least 12 months may be employed below $€ 8.50$ for up to six months. However, vom Berge et al. (2016) show that this exemption is rarely used. Yet the exception for trainees and minors reduces the number of eligible individuals substantially. In 2014, about 5.5 million employees earned less than $€ 8.50$ per hour, and four million of them (72 percent) were eligible for the minimum wage (Destatis, 2016). Within this number, three groups of employed people are over-represented: East German residents, "mini-jobbers", and women. While the first group results from the continuing structural differences between East and West Germany, as evident in different price levels, the third group results from the gender wage gap and the higher proportion of part-time work. The second group, employees in "mini-jobs", are not subject to paying social security contributions. In many cases, their gross income is therefore equal to their net income, meaning that their wages are not entirely comparable with regular wages.

Enforcement. The German Customs Administration is responsible for conducting inspections of employer firms and enforcing compliance with social security laws and the Minimum Wage Law. If it finds noncompliance, prosecutors may impose fines up to $€ 500,000$. According to a report to German Parliament, ${ }^{6}$ the Customs Administration conducted 63,014 inspections of firms in 2014 and 43,637 inspections in 2015, implying a 30 percent reduction in inspections in the post-reform year. According to another report to German Parliament, 705 legal proceedings were initiated in 2015 and the total sum of resulting fines was around $€ 194,000$ (see Deutscher Bundestag, 2016b, p. 10). Thus, legal proceedings were initiated in 1.6 out of 100 inspections, and the average fine was about $€ 275$.

\section{Distributional effects of minimum wages}

The literature on minimum wage reforms to date has focused primarily on two economic outcomes: wage inequality and employment. The challenge these studies face lies in identifying the impacts of the given reform. To do so, they rely on three main sources of variation in treatment intensity: variation over time, economic sectors, and regions. In the following, we explain the

\footnotetext{
${ }^{6}$ See Deutscher Bundestag (2016a).
} 
main ideas behind these identification strategies and their applicability to the German case. We then give an overview of key findings on the relationship between minimum wages and the wage distribution that can be drawn from the literature.

Identification using variation in treatment intensity over time. One strand of the literature has studied wage inequality by exploiting inter-temporal variation in minimum wages, be it because the minimum wage is adjusted over time or because a minimum wage has been newly introduced. Such an application for the United Kingdom can be found in Dickens and Manning (2004a,b). The authors rely on inter-temporal changes in minimum wages and find that the introduction of minimum wages in 1999 diminished wage inequality. Other applications include Amlinger et al. (2016) and Mindestlohnkommission (2016a) for Germany, which compare wage growth before and after the German minimum wage reform. Their findings show that lowwage groups such as unskilled workers, women, part-time employees in small firms, and employees in East Germany experienced the strongest wage growth after the implementation of the reform. Since multiple factors besides the minimum wage may affect the wage distribution, the observed changes are not directly attributable to minimum wage reforms and cannot be assumed to be causal.

Identification using variation of treatment by economic sectors. Another strand of the literature has exploited variation in the level of minimum wages across economic sectors and over time. This approach has been used extensively to evaluate German sector-specific minimum wages (Fitzenberger and Doerr, 2016). In a study on the construction sector, König and Möller (2009) compared wages below and above the minimum wage threshold and reported a positive redistributional effect of the minimum wage. A study by Frings (2013) evaluated the effect of minimum wages on painters and electricians, using the transport and communication industry and the wholesale and retail sectors as control groups. The main challenge of this identification strategy lies in the choice of the control group - either within the same sector, or from other sectors. The control group should be highly comparable to the treatment group and should also not be exposed to spillover effects within and between sectors.

Identification using variation over regions. Inter-regional variation of minimum wages arises due to legislative differences in minimum wage settings and/or variation in wage structures causing differences in the regional "bite" of the minimum wage. The seminal paper on the 
subject was written by Card and Krueger (1992), who investigated the implications of differences in minimum wage levels. Card (1992b) and Dube et al. (2010) followed up on this in a paper exploiting the regional variation across all US states. The approach was applied to wage inequality in a paper by Lee (1999), who found that regions with a higher minimum wage bite exhibit a higher decline in inequality at the bottom of the wage distribution. For the United Kingdom, Dolton et al. (2012) exploited the variation in the bite of the national minimum wage across local labor markets and time, and found that an increased bite is associated with lower inequality at the bottom of the wage distribution.

Main empirical facts The general message of the empirical literature is that minimum wages mitigate wage inequalities. However, studies vary with respect to the magnitude of this effect (see Lee, 1999; Teulings, 2003; DiNardo et al., 1996; Autor et al., 2016). Several studies have also investigated spillover effects to higher-wage segments, but come to divergent conclusions (Autor et al., 2016; Dickens and Manning, 2004a; Stewart, 2012). However, Autor et al. (2016) mentions that the nature of spillovers is not fully understood and might be at least partly attributed to errors in measuring wages in survey data.

There are also a number of studies in the literature on factors that prevent minimum wages from exerting their full impact. One such factor is noncompliance (Brown, 1999; Metcalf, 2008; Mindestlohnkommission, 2016a), i.e., observed wages below the minimum wage threshold for the eligible population. Other studies warn that general equilibrium effects, such as reductions in employment or working hours, may balance out the inequality-reducing effect of minimum wage reforms (Neumark et al., 2004), particularly in the long run. The long-run effects also hinge on the how minimum wages affect schooling (Neumark and Wascher, 1995) and on-the-job training (Neumark and Wascher, 2001).

\section{Data}

In the subsequent empirical analysis, we investigate hourly wages, workings hours, and monthly earnings before and after the introduction of the minimum wage reform. Our analysis relies on data from the German Socio-Economic Panel (SOEP), an ongoing representative longitudinal panel survey with about 30,000 survey participants in 15,000 households per year (see Wagner et al., 2007). We use SOEP version 32.1 and consider individual-level data from 2012 to 2015 (see SOEP v32, 2016). The majority of the SOEP data are gathered between February and June, 
implying that our results describe short-term effects in the first half year after the reform's implementation. In the following, we describe the core variables and the composition of our working sample.

\subsection{Core variables for the empirical analysis}

The SOEP does not include a question asking respondents to state their hourly wages, but does allow for computation of hourly wages as the ratio of gross monthly earnings and weekly working hours adjusted by average weeks per month. ${ }^{7}$ Hours are stated in the SOEP as actual and contractual weekly working hours. While the latter are the number of hours determined in the employment contract, actual hours include overtime worked. Hourly wages can therefore be constructed with either measure of working hours, producing two different wage concepts: actual and contractual hourly wages. Both wage concepts have advantages. From a legal perspective, minimum wage regulations are binding for any number of working hours, including overtime. Actual wages are thus the policy target and the center of interest, but also the blind spot of administrative data. However, gross monthly income is surveyed for the previous month only, whereas working hours are surveyed for the current point in time. Therefore, a specific monthly income does not necessarily relate to the working hours and overtime associated with it. Yet overtime is relatively time-variant, which means calculating current overtime based on the previous month's income may cause measurement issues. Both definitions are therefore used parallel to achieve a full picture.

Having hourly wages, hours worked, and earnings in addition to detailed socio-demographic information is a key advantage of the SOEP data. Administrative data usually cannot provide the same density of information on a regular basis, especially with respect to unpaid overtime. Survey data are, however, prone to imprecision. Item non-response or rounded answers (e.g., "humping") may bias hourly wage computations. In Section 7, we discuss potential sources of imprecise measurement.

\subsection{Working sample}

In our analysis, we focus on those employees in Germany who are eligible for the minimum wage. Hence, we exclude individuals belonging to the groups and sectors that are exempted from the reform. ${ }^{8}$ In order to prevent outliers in hourly wages from biasing our results, we winsorize the

\footnotetext{
${ }^{7}$ http://www.diw.de/en/diw_02.c.222729.en/questionnaires.html, last accessed on December 14, 2017.

${ }^{8}$ See Appendix B for the construction of the corresponding restrictions.
} 
data by setting the top and bottom one percent of hourly wages to the value of the first and 99th percentiles, respectively. By limiting the restrictions on the SOEP to a minimum, we aim to preserve the representative character of the data.

The DiD analysis relies on the wage distributions of Germany's planning regions to infer the region-specific treatment intensity. Germany is subdivided into 96 planning regions. The treatment intensity is derived from the region-specific wage distributions according to the SOEP. In some planning regions, sample sizes are relatively small, calling the precision of the derived treatment intensity into question. We decided to discard regions with fewer than 30 observations in order to guarantee valid descriptions of the included regional wage distributions while not losing too many regions. This leaves us with 92 regions for the DiD analysis. These restrictions determine the first working sample, Sample 1.

In parts of the analysis, we also make use of the longitudinal character of the SOEP to analyze individual changes in wages, earnings, and hours. For this, we further restrict Sample 1 to those individuals with consecutive wage information. The resulting sample in the following Sample 2 includes all individuals from Sample 1 who also reported an eligible status and wage information in the previous year. In addition, several pieces of information on socio-economic background must be available in order to control for selection processes in the regression model. This includes information about gender, age, German citizenship, presence of children in the household below the age of 16, and marital status. By construction, as Sample 2 conditions on employment, analyses using this sample say nothing about the reform's effects on those who entered or left the labor force between 2014 and 2015. However, the short-term effects of the reform on employment are shown to be minor and thus negligible for our analysis (Mindestlohnkommission, 2016a; Bossler and Gerner, 2016; Caliendo et al., 2017).

Since the legislative process started in late 2013, anticipatory effects may have affected wages before January 1, 2015. Hence, the analysis will include samples from the years 2013 to 2015. Overall, 35,326 observations are available in Sample 1 for 2013, 2014, and 2015. Due to item-nonresponse, panel attrition, and changes in employment status, the additional restrictions on the longitudinal analysis reduce the number of observations to 18,098. Table 1 presents the losses in observations for each imposed restriction and the resulting sample sizes of our working samples. Section 7 provides a robustness check of our main results in order to show that additional restrictions imposed in Sample 2 do not harm the representativeness of our data.

$$
<<\text { Table } 1 \text { about here }>>
$$




\section{Descriptive evidence}

\subsection{Wage Distribution: The Pen's Parade of Dwarfs}

First, we compare wage distributions of the years 2013 to 2015 to evaluate the overall change in wages. These comparisons will be based on cross-sectional samples. This means that all employees in a year are considered. However, wages of persons entering the labor market in, say, 2014 are not included in 2013, and wages of persons leaving the work force in 2014 are not included in 2015. In the following, Pen's Parade of Dwarfs is used as a graphical description of the wage distribution. This parade is derived from Sample 1 and plots hourly wages over the percentiles of hourly wages. ${ }^{9}$

Figure 1 illustrates the shift in the wage distribution of contractual hourly wages (upper panel) and actual hourly wages (lower panel) after the minimum wage reform. The left graph provides Pen's Parades for the bottom forty percentiles of the respective distribution for 2013 to 2015 . The red horizontal line indicates the threshold value of $€ 8.50$. The right graph provides the vertical differences of Pen's Parades for consecutive years, that is, the percentile-specific inter-temporal changes in wages.

The upper-left panel of Figure 1 shows that in 2013 and 2014, about 9 percent of Sample 1 earned less than $€ 8.50$ according to their contractual hourly wage. In 2015 , wages of the bottom 40 percent increased, but about 7 percent of the eligible population remained under the $€ 8.50$ threshold. The upper-right panel of Figure 1 shows that, between 2013 and 2014, changes in contractual wages for the bottom 40 percent of the wage distribution were small in quantitative terms. This picture changes in 2014 and 2015. Here we observe a noticeable rise in hourly wages of about $€ 0.60$.

The lower panel of Figure 1 provides Pen's Parades for actual hourly wages. The share of employed people paid below the minimum wage according to their actual hourly wages is about 10 percent and is slightly larger than the corresponding share measured by contractual hourly wages. In particular, this reflects the fact that the distribution of actual hourly wages is statistically dominated by the distribution of contractual hourly wages. At the bottom of the actual hourly wage distribution, we also find higher annual growth rates in 2015 than in 2014.

While Pen's Parades indicate considerable increases in wages in the low-wage segment in the first half of 2015, a substantial share of eligible employees are still paid below the minimum

\footnotetext{
${ }^{9}$ Given the size of Sample 1 (see Table 1 for details), percentiles have, on average, 111 observations in 2013, 103 observations in 2014, and 92 observations in 2015.
} 
wage. Measurement error in our data may explain part of this result, an issue we will return to in a sensitivity analysis in Section 7. Another interpretation is that employers do not remunerate all their employees in accordance with the law. This interpretation is supported by the first report of the German Minimum Wage Commission. The Commission has access to the 2015 Earnings Survey (Verdiensterhebung), a firm-level survey, and estimates that noncompliance affects about 2.7 percent of employees (Mindestlohnkommission, 2016a, p. 50). This number is substantially lower than our estimates. Notice, however, that the Earnings Survey does not claim to be representative, as firms' participation was voluntary, with relatively low response rates and systematic unit-non-response (Destatis, 2015, pp. 25 and 60).

$<<$ Figure 1 about here $>>$

Figure A.1 in the Appendix A presents Pen's Parades by employment category. As already argued, mini-jobbers are affected most by the reform. About 45 percent of all mini-jobbers were employed below the minimum wage in 2014. After the reform, about 33 percent were paid below this level. Wage growth was more pronounced for this than for other employment types. Especially in comparison with the pre-reform period, almost all affected percentiles benefited from the reform. However, a large percentage of mini-jobbers are still paid less than stipulated by law. In full-time employment, the share of beneficiaries has been relatively small from the outset. In 2014, about 6 percent of all full-time employed people were paid less than $€ 8.50$. Compared to the wage growth between 2013 and 2014, in 2015 it was more in the lower quintiles of full-time employed people where wage growth occurred, with only 5 percent still being paid below the minimum wage. People employed part-time have benefited slightly. In 2014, about 7 percent of all part-timers were paid below the minimum wage. In 2015, this share was about 6 percent.

\subsection{Decomposing the low-wage segment: The Sen index of gross hourly wages}

To shed more light on those individuals still earning less than the minimum wage after the reform, we focus in the following on various distributional characteristics of the low-wage segment. For this purpose, we make use of the concept of the Sen index. This index is usually applied in poverty analysis to examine the incidence and intensity of poverty in a coherent framework. The poor are defined as the population falling below a particular income threshold, the poverty line. For our purposes, we derive the Sen index from contractual and actual gross hourly wage distributions and use the minimum wage of $€ 8.50$ as a substitute for the poverty line. 
The Sen index is defined as, $P_{S e n}=H \times G_{z}+P \times\left(1-G_{z}\right)$, and builds on three subcomponents. The head-count ratio $H$ is defined as the fraction of the population, $i=1, \ldots, N$, with wages, $w_{i}$, below the threshold $z=8.50$. The Gini coefficient, $G_{z}$, describes the statistical dispersion among the population below the minimum wage threshold. The higher $G_{z}$, the higher the inequality. $P$ is the poverty gap, which represents the average relative distance to $z, P=$ $\frac{1}{N} \sum_{j=1}^{q}\left(\frac{z-w_{j}}{z}\right)$, with $j=1, \ldots, q$ denoting the individuals with $w_{j}<z$. In our context, $P$ can be referred to as minimum wage gap. Because of its three different components, the Sen index allows decomposition into three potential sources of distributional changes: a reduction in the number of those affected, an overall shift towards the minimum wage threshold, or an equalization of wages. Under full compliance and in the absence of measurement error, the Sen index should be zero. Contrarily, the index can increase up to 1 if $H$ and $G_{z}$ get closer to 1 .

Table 2 provides the Sen index and its three sub-components for the period from 2013 to 2015. The upper panel provides the results for the concept of contractual hourly wages, the bottom panel for actual hourly wages. We use the bootstrap resampling method to determine confidence intervals of our estimates.

\section{$<<$ Table 2 about here $>>$}

For the contractual hourly wage, the Sen index is approximately constant for the two prereform years at about 2.6 percent. The same holds for the head-count ratio (about 9 percent), the Gini coefficient for wages below the threshold (about 10 percent), and the minimum wage gap (about 1.8 percent). After the reform, the Sen index decreases to about 1.9 percent. The main driver of the decrease is the drop in the head count ratio. While about 9 percent earned less than $€ 8.50$ in 2014 , this fraction was about seven percent in 2015. The Gini coefficient did not improve, potentially suggesting existence of low-wage segments not reached by the reform. The minimum wage gap decreased from about 1.9 percent in 2014 to 1.3 percent in 2015, suggesting an improvement in hourly wages, also among those whose wages were still below the minimum wage.

In accordance with the previous graphical analysis, the Sen index and its components are higher in levels for actual hourly wages. However, the inter-temporal comparison yields the same conclusions. After the reform, the Sen index decreased considerably. The main driver of the reduction was a lower head count and, to a lesser extent, the minimum wage gap, whereas the Gini coefficient for wages below the minimum wage did not improve. 
As for Pen's Parades, we also provide estimates for the sub-groups of full-time, part-time, and marginally employed people. Because the results are very similar for both wage concepts, we restrict our attention to contractual hourly wages. Summaries are compiled in Table A.1 in Appendix A. Comparing the groups, the Sen index is the lowest for the full-time employed, higher for part-time employees, and the highest for the marginally employed. For the full-time employed, the index falls from 1.7 percent in 2013 to 1.3 percent in 2015 . For the part-time employed, the index is higher, but also falls - from 1.8 percent in 2013 to 1.4 percent in 2015. For marginal employees, the Sen index is by far the highest, but also exhibits the most pronounced reduction - from 13.5 percent in 2013 to 10.3 percent in 2015. For all three groups, a lowering of the head count is the predominant driver, while the minimum wage gap changes only slightly and the Gini coefficient either does not change or increases (for full-time employed).

\subsection{Composition of population with wages below $€ 8.50$}

Pen's Parades and the Sen index have provided evidence of a substantial share of workers earning below $€ 8.50$ before the minimum wage reform as well as after its introduction. We also have shown that the incidence of such low wages is more likely to be observed among part-time workers and especially among mini-job workers. Table 3 compares the composition of Sample 1 with the composition of the sub-group of workers with contractual hourly wages below $€ 8.50$ in 2013, 2014, and 2015. Recall that, by construction, Sample 1 contains only employees eligible for the minimum wage.

$<<$ Table 3 about here $>>$

There are several groups that are overrepresented in the low-wage segment of interest. In 2013, East German residents, women, migrants, singles and low-educated workers had a higher likelihood of being paid below $€ 8.50$ per hour (this is in line with statistics reported by, e.g., Brautzsch and Schultz, 2013; Brenke, 2014). The socio-demographic characteristics of age and children in the household do not indicate any differences between those earning less than or more than $€ 8.50$ per hour. In the following years, the share of low-educated workers, singles and German citizens remained relatively stable in the group of low-paid workers. In contrast, the share of East German residents decreased and the share of women increased from 2013 onwards. From this descriptive perspective, a specific effect of the minimum wage reform in 2015 on the composition of the low-wage segment cannot be observed. 
As differences by gender and region are most prevalent, the Sen index is applied to these groups separately (see Tables A.2 and A.3 in the Appendix A). The Sen index for men is more than two times lower than for women, both before and after the implementation of the minimum wage reform. This difference is due mainly to the head count and the minimum wage gap. Hence, women are not only more often paid below $€ 8.50$ per hour, but also have a higher average distance to the threshold. This has not changed since the minimum wage reform. In 2015, the Sen index was twice as high for women as for men (1.3 and 2.5 percent, respectively).

Table A.3 reports the Sen index and its components for East and West Germany. In East Germany, the Sen index and its components are substantially higher than in West Germany, mainly due to the head count and the minimum wage gap. However, both absolute and relative adjustments of the head count and the minimum wage gap are higher in East Germany than in West Germany, resulting in a less than one-point difference in the Sen index after the reform's implementation. This evidence demonstrates that, after the reform was implemented, there was more wage adjustment between regions than between genders.

\subsection{Changes in monthly earnings}

The main policy target of the minimum wage reform was to improve the monthly earnings of low-wage workers. ${ }^{10}$ Whether the observed increase of hourly wages at the bottom translates into higher monthly gross earnings, however, is an open question. If labor demand declines due to increased labor costs on the intensive margin, a rise in hourly wages will not translate proportionately into higher monthly earnings.

We first study the distribution of gross monthly earnings by means of Pen's Parades to visualize the changes after the introduction of the minimum wage. Figures 2 and A.2 provide Pen's Parades for the entire eligible population and for different types of employment, focusing on the bottom 40 percent of the respective populations. For both figures, we construct percentiles based on the distribution of monthly earnings. For the entire eligible population (Figure 2), monthly earnings changed little in 2013 and 2014, especially below the 25th percentile. Between 2014 and 2015, the Pen's Parade shifted upwards, suggesting slightly higher earnings in virtually all of the bottom 40 percentiles. In the bottom ten percentiles, earnings increased by less than $€ 50$.

\footnotetext{
${ }^{10}$ See https://www.bundestag.de/dokumente/textarchiv/2014/kw27_de_tarifautonomie/286268, last accessed on December 14, 2017.
} 
$<<$ Figure 2 about here $>>$

Pen's Parades by employment type (Figure A.2 in the Appendix) reveal that full-time employees were the main beneficiary of the 2014 to 2015 increase in monthly earnings. For part-time employees, monthly earnings improved by about $€ 50$ only from the tenth percentile upward. For mini-job holders, monthly earnings increased by up to $€ 40$.

Recall that Figures 2 and A.2 rely on the percentiles of the distribution of monthly earnings. Thus, although we observe some growth at the bottom of this distribution, it is not directly attributable to the minimum wage reform. When plotted in the percentiles of contractual or actual hourly wages, changes in monthly earnings do not show any systematic pattern. In particular, they do not indicate an increase in monthly earnings at the low end of the hourly wage distribution. ${ }^{11}$

\section{Difference-in-differences analysis}

\subsection{General framework}

Because the statutory minimum wage in Germany is uniform in all regions and for basically all employees, identifying the reform's effect on wages is not straightforward. In the following, we apply the identification strategy suggested by Card (1992b). To estimate the causal effect of minimum wages on employment, he proposes using regional differences in relative treatment intensity. In Germany, the minimum wage is uniform across all regions but hourly wage distributions are relatively different across regions. This gives rise to variation in the bite (treatment intensity) of the reform, measured by the regional shares of employees paid below the minimum wage in the years prior to the reform. For the reform to be effective, we should find that it has a larger effect on regional wages in higher-treated regions. However, low productivity and profitability of the resident firms in highly treated regions may weaken this effect.

One threat to the region-based identification is the spatial dependency of regions, which creates a bias in the regional effects of the minimum wage reform. However, Dolton et al. (2015) show that controlling for region-specific gross domestic product or gross value added removes the main estimation bias. The resulting estimates should therefore not differ systematically from estimates based on specifications that control for spatial dependency of regions. Another threat is that the regional bite is correlated with regional economic performance. For example, if the

\footnotetext{
${ }^{11}$ Corresponding figures are available upon request.
} 
reform's bite in economically weak regions is high, these regions should exhibit the highest wage adjustment. Therefore, as mentioned by Dube et al. (2010) and Dolton et al. (2015), the underlying regression equation should include controls for economic performance, such as , e.g., lagged region-specific GDP per capita.

Following this rationale, our basic regression equation takes the form,

$$
\log \left(w_{i r t}^{k}\right)=\alpha+\beta \times D_{t}^{2015}+\gamma B i t e_{r}^{2013}+\delta\left(D_{t}^{2015} \times \text { Bite }_{r}^{2013}\right)+\mu \mathbf{X}_{\text {irt }}+\epsilon_{\text {irt }} .
$$

The dependent variable is the log of hourly gross wages of type $k=\{$ contractual, actual $\}$ of individual $i$ at time $t \in(2014,2015)$ residing in region $r$. It is dependent on a period dummy variable $D_{t}^{2015}$ equal to one for all observations in the post-reform year. Bite $e_{r}^{2013}$ captures the treatment intensity measured by the regional fractions of eligible employees with contractual hourly wages below $€ 8.50$ normalized by the average regional bite. Because of the possibility of anticipation effects and in order to avoid endogeneity, we use the bite for 2013. The associated regression coefficient captures differential changes in wages dependent on the regional treatment intensity. Accordingly, the interaction between the period dummy and the treatment intensity allows $\delta$ to capture the treatment effect of the reform.

Additionally, the model includes a set of explanatory variables, $\mathbf{X}_{i r t}$, encompassing gender, age, marital status, German citizenship, presence of children aged below 16 in the household, as well as two-period lagged regional GDP per capita (inclusion of pre-reform controls for regional economic condition is suggested by Dube et al., 2010; Dolton et al., 2015). Finally, $\epsilon_{i, r, t}$ represents the error term.

Based on Equation (1), we estimate a pooled OLS regression and an individual fixed-effect model for Sample 2. In the OLS model, the coefficient $\delta$ is interpreted as wage growth in 2015 in regions with average treatment intensity. In the FE model, the same coefficient refers to average individual wage growth, as this model controls for time-invariant individual characteristics (e.g., motivation, ability, or bargaining power).

Using both methods, we first estimate the average treatment effect at the mean of the regional wage distributions. Additionally, we estimate Equation (1) separately by quintiles of the regional wage distributions, with individuals being assigned to their position in the (unweighted) regional distribution in 2013. ${ }^{12}$ The upper panel of Table A.4 in the Appendix A summarizes the number

\footnotetext{
${ }^{12}$ Because Sample 2, which is used for the analysis, is smaller than Sample 1, we define the region-specific quintiles based on Sample 1. A check presented in Section 7 rejects the systematic nature of these dropouts and confirms our main results.
} 
of observations and mean wages by quintiles. By construction, the number of observations is evenly distributed between the quintiles. Furthermore, we also use the framework described in Equation (1) to study the treatment effects on log monthly earnings and log hours worked as dependent variables.

The regional treatment intensity is defined as the eligible share of employees paid less than the minimum wage prior to the reform (in 2013). These shares are derived from the SOEP. As explained above, we assign the employed to 96 "planning regions" (Raumordnungregionen (ROR), see BBSR, 2016), a concept that is frequently used in the regional analysis of infrastructure, economic situations, and investments (e.g., see Funke and Niebuhr, 2005). ${ }^{13}$ On average, we rely on 65 individuals per region and year. As bite indicator, we use the weighted share of the eligible employed with contractual hourly wages below the minimum wage threshold. We use contractual hours here because these are less prone to measurement error cpmpared to actual hourly wages. As can be seen from Figure 3, the bite varies considerably between regions. Many regions with high treatment are located in the East; many regions with low treatment in the Southwest. Although the number of observations in each region is small in the SOEP, Caliendo et al. (2017) show that SOEP-based bite indicators are highly correlated with bites constructed from the more comprehensive Structure of Earnings Survey (SES).

$$
<<\text { Figure } 3 \text { about here }>>
$$

\subsection{Parallel trends assumption}

To identify the reform's effects, it is crucial that the parallel trend assumption holds for the treatment and control groups. In the following, we provide a visual representation of parallel trends of the mean and percentiles of the unconditional distribution of contractual gross hourly wages. While treatment intensity is a continuous variable, we conduct a graphical inspection by distinguishing regions with "low," "medium," and "high" treatment intensity following Card (1992b). The three types of regions are distinguished by sorting regions by increasing order of bite in 2013, and then splitting the sorted regions into thirds.

The Figure 4a provides means of contractual gross hourly wages for the three types of regions for the 2012 to 2015 period. The visual indications for the pre-reform period support the parallel trends assumption within the 95-percent confidence intervals: while mean wages across "low," "medium," and "high" treatment regions differ by definition, the slopes of the time trends for the

\footnotetext{
${ }^{13}$ For our regional assignment of the employed, we use the SOEP variable region of residence.
} 
three types of regions are basically the same. The graph also suggests no reform-induced changes in average wage growth. Figure $4 \mathrm{~b}$ plots the time trends for the three bottom wage quintiles. In general, wages grow in all regions and all three quintiles. The only exception is the bottom quintile in the period 2012 to 2013 in highly treated regions, where we find stagnating wages. Between 2014 and 2015, the lowest quintile in highly treated regions exhibits above-average growth. This can be seen as an indication of the effectiveness of the reform. However, the figures presented rely on the division into three groups by treatment intensity and show the evolution of unconditional hourly wages. Therefore, they only roughly reflect the identification strategy. In Section 6.5 we show that the parallel trend assumption holds in a conditional placebo estimation that reproduces the actual identification design.

$<<$ Figure 4 about here $>>$

\subsection{Effect on hourly wages}

Table 4 provides the coefficients of the treatment effect, $\delta$, from the above-introduced regression Equation (1). ${ }^{14}$ The left column contains the OLS estimates and the right column the fixed-effects regression estimates. The baseline estimation, in short "base", uses the full sample, but does not include any additional controls $\left(\mathbf{X}_{i r t}\right)$. The estimation called "base + socio-demographics" includes these individual and regional characteristics. In a further step, we focus on individuals in specific quintiles, i.e., Q1 to Q5. Here, the estimations are summarized as "base by quintiles" and "base + socio-demographics by quintiles".

First we discuss the results of the estimations for the mean of the entire distribution of contractual hourly wages (upper panel). The results show that the estimates of $\delta$ at the mean are positive, but only weak or not significantly different from zero. These results suggest that the minimum wage reform had only a small, if any, positive effect on the average wage of the eligible population.

Focusing on the subgroup at which the reform was aimed, employees with low wages, we now turn to OLS regressions by quintiles of the regional wage distribution. For the first quintile, we find highly significant and positive treatment effects of 0.064 when estimated without additional controls, and 0.065 when including the set of additional controls. A coefficient of 0.065 means that, in a region with the average treatment intensity (normalized to be 1.0), wages in the first quintile grew by 6.5 percent. Wages above the 20 th percentile of the regional distributions have

\footnotetext{
${ }^{14}$ Tables with details on all estimated coefficients are available upon request.
} 
not been affected by the reform. When including individual fixed effects, average wage growth in the first quintile changes only slightly -6.6 percent without additional controls and 5.8 percent when including the additional controls. The difference between the OLS and FE results implies positive selection on time-fixed unobservables into wage growth due to the minimum wage reform.

In general, similar results can be found when estimating effects on actual hourly wages (lower panel). Taken together, even though the descriptive analyses implied a high level of noncompliance, average wages within the bottom quintile have been growing faster in highly affected areas. ${ }^{15}$

$<<$ Table 4 about here $>>$

\subsection{Effect on monthly earnings and hours worked}

The above DiD framework also allows for estimating the effect of the minimum wage reform on monthly earnings and hours worked. In the following, we re-estimate Equation (1), replacing the left-hand variable by the logarithm of monthly gross earnings, log contractual hours worked, and log actual hours worked. In the following, we focus on our preferred models - the OLS and fixed effects models - using the full set of controls. Table 5 summarizes the DiD results.

\section{$<<$ Table 5 about here $>>$}

For log monthly earnings in 2014 and 2015, estimations show small positive but insignificant effects on monthly earnings in the first quintile. Looking at the results alongside those reported above, monthly earnings did not grow by the same amount as hourly wages, which should have occurred if hours did not change. For contractual working hours, we find a negative treatment effect for the bottom quintile of the hourly wage distribution of 6.2 percent in the OLS and 3.5 percent in the FE estimation. This means that the reform reduced contractual working hours more among low-paid employees in highly treated regions. Focusing on actual working hours, i.e., contractual working hours plus any paid or unpaid overtime, we find a negative effect of 4.8 percent for the first quintile in the OLS and a reduction of 3.1 percent in the FE.

The above evidence suggests that the increase in hourly wages after the minimum wage reform was accompanied by a reduction in hours worked. This reduction is more pronounced

\footnotetext{
${ }^{15}$ We also ran the estimation with the treatment intensity defined by the actual hourly wage and obtained qualitatively similar results. They are available from the authors upon request.
} 
for contractual hours than for actual hours worked, and is driven by selection on time-invariant individual characteristics. In sum, the increase in hourly wages and the decrease in working hours leave monthly earnings unchanged. One plausible explanation for the negative treatment effect is that employers reduce hours worked in an attempt to diminish labor costs at the intensive margin. Another explanation is that employees lower their labor supply themselves in response to the reform in order to not exceed earnings limits that secure access to particular social security or tax advantages.

\subsection{Placebo regressions}

This section addresses the validity of the common trend assumption for contractual hourly wages, monthly earnings, and working hours (contractual and actual). The graphical representations in Subsection 6.2 provide supportive descriptive evidence, but do not reproduce the DiD regression design in detail. Here we explicitly check the common trend assumption by means of placebo regressions. The minimum wage was introduced on January 1, 2015, and for this reason, the treatment effects above are derived by comparing the wage distributions from 2014 and 2015 using regional bites from 2013. In the placebo regressions, we estimate a model with lagged variables, i.e., with wage distributions from 2013 and 2014 and the regional bite from 2012 . If the common trend assumption is true, we would expect to find no treatment effect in this placebo regression. The regression equation takes the form,

$$
\log \left(y_{\text {irt }}\right)=\alpha+\beta \times D_{t}^{2014}+\gamma \text { Bite }_{r}^{2012}+\delta\left(D_{t}^{2014} \times \text { Bite }_{r}^{2012}\right)+\mu \mathbf{X}_{\text {irt }}+\epsilon_{\text {irt }},
$$

with $y_{\text {irt }}$ denoting one of the four aforementioned dependent variables and $t \in(2013,2014)$.

$$
<<\text { Table } 6 \text { about here }>>
$$

In sum, the placebo estimations (see Table 6) give evidence supporting the parallel trend assumption, and lend credibility to our identification strategy. For the OLS, we find a downward adjustment of hourly wages in the first quintile. For the FE this is not the case. For monthly earnings and hours worked, we do not find any significant changes in the first quintile. In the upper quintiles, some of the placebo estimations exhibit significant coefficients. However, their appearance is not systematic with respect to the estimation model (OLS and FE). ${ }^{16}$ The results

\footnotetext{
${ }^{16}$ Moreover, their apperance is not systematic when we vary the set of socio-demographic controls. Another formal test of the (non-)systematic appearance of significant coefficients can be done using bootstrapping of the coefficients using random assignment of the treatment intensity to regions (Bonferroni correction).
} 
suggest that if anticipation of the reform took place, it was directed towards a reduction in wages and earnings. Therefore, our results for 2014 and 2015 tend to overestimate the effect on hourly wages and monthly earnings in the OLS.

\section{Robustness checks}

Due to its panel character and its manifold information on socio-demographics and job characteristics, the SOEP has several advantages in comparison with other datasets. But, as participants answer questions by themselves, data on working hours or monthly earnings might be rounded or even missing, implying measurement or selection issues. In order to evaluate whether such concerns affect our results, the following Section will discuss data limitations of the SOEP.

Measurement error In survey data, reported earnings and working hours are susceptible to systematic errors in answers. Potentially resulting measurement errors are particularly problematic if respondents systematically under-report their earnings and over-report their working hours. In this case, we will underestimate hourly wages and overestimate noncompliance.

We cannot directly estimate the extent of measurement error. However, we can make assumptions about the magnitude of the bias and how it affects the extent of measured noncompliance and inequality at the bottom of the wage distribution. In particular, we compute the Sen index and its sub-components under the assumption that the minimum wage is five or ten percent lower than the official threshold of $€ 8.50$.

The results are summarized in Table 7 for both hourly wage concepts. Lowering the minimum wage threshold lowers all three components of the Sen index. In particular, it lowers the head count, which measures (in absence of any measurement errors) noncompliance. For example, for the contractual hourly wage, the head count for the year 2015 drops from 6.8 percent ${ }^{17}$ to 5.4 percent if the minimum wage threshold is lowered by five percent, and to 4.5 percent if lowered by ten percent. This level effect, however, does not alter our conclusion about the relatively small distributional effect of the reform or the observation of high noncompliance: For all assumed thresholds, the Sen index and all its subcomponents fall after the minimum wage reform, but not to the intended degree.

\section{$<<$ Table 7 about here $>>$}

${ }^{17}$ As reported in Table 2. 
This measurement issue could also affect our estimation from the previous Section, but a regionally equiproportionate bias is innocuous for the results. If the error is randomly distributed, variation increases, which solely diminishes the standard deviation of the coefficients. Only if the measurement error is correlated with the treatment intensity is a non-systematic bias problematic. However, we do not see any way to test whether this is the case with the data available.

Wage outliers and item non-response Not all respondents provide answers to all SOEP questions. If non-response is systematic, this creates another element of uncertainty. For example, if individuals with low earnings are less likely to report their earnings, this would lead to an underestimation of the share of low-wage employees. ${ }^{18}$ For concerns like this, some missing values are statistically imputed. This is also the case for monthly gross earnings but not for working hours. Because of this non-imputation and because imputations are accompanied by additional uncertainty, following Autor et al. (2016), we decided to discard observations with imputed earnings.

In the following, we investigate how including imputed values alters the results for the variable of interest, contractual hourly wages. We redo the calculations of the Sen index for Sample 1 and the estimation of the treatment effects for Sample 2 integrating the previously discarded imputed wages.

Table 8 summarizes the Sen for the original Sample 1 and the new working sample with imputed wages. Compared to Sample 1, the new sample leads to an increase in the Sen index. The Gini coefficient for the observations with wages below the minimum wage is most responsive. It increases even more in the post-reform period, suggesting that the reform did not have the desired positive effect at the bottom of the wage distribution. For the head count, the minimum wage gap, and the Sen index, however, we still observe the aforementioned positive influence of the reform. ${ }^{19}$

$<<$ Table 8 about here $>>$

Next we redo the DiD estimations for hourly wages based on the new samples with imputed wages. Table 9 summarizes the results. While there are some minor differences in the size of the coefficients compared to the results of the main analysis, the table reconfirms our previous

\footnotetext{
${ }^{18}$ For the structure of item non-response on income and wealth questions in SOEP, see Frick and Grabka (2005); Frick et al. (2007).

${ }^{19}$ All the summarized results also carry over to the actual hourly wage. Results can be provided upon request.
} 
evidence: The reform has no or only a small effect on the mean wage; it has strong positive effects in the first quintile, and no pronounced effects in the second to fifth quintile.

$<<$ Table 9 about here $>>$

Sample representativeness As presented in Table 1, the number of observations in our working Sample 2 is substantially lower than in Sample 1, mainly due to the restriction on the consecutive biannual wage information that is required to estimate regression equation 1 with individual fixed effects. For the sake of comparison, our main results both for the OLS and FE models based on same respondents (Sample 2). However, the OLS results are technically possible to obtain using the bigger Sample 1. Table 10 compares the OLS coefficients based on Sample 2 (left panel) and Sample 1 (right panel). The results are robust to the change in the working sample. For contractual hourly wages, we find disproportionate wage growth in the first quintile in both samples. In Sample 1, we additionally find a small negative effect in the third quintile, indicating compression of the wage distribution.

$<<$ Table 10 about here $>>$

Alternative bite measure The analysis presented here relies on a bite measure constructed from the SOEP data. In some regions, numbers of observations in SOEP are small, calling the validity of the derived bite into question. This is a threat to our identification strategy, particularly if the measurement error is systematic. For this reason, we re-ran our analysis using a bite constructed from administrative large-scale data, the Structure of Earnings Survey (SES). ${ }^{20}$ Unfortunately, the data are available only for 2014, but not for our preferred period, 2013, meaning that anticipatory effects may already have taken effect on the bite. However, in a companion paper (Caliendo et al., 2017) we show that there were no anticipation effects on wages. Table 11 replicates the main analyses for hourly wages, except that instead of the SOEP-based bite for 2013 we use the SES-based bite for 2014. In general, the results using the SES-based bite confirm the presence of wage growth in the first quintile. For the OLS, the negative effect in the third quintile indicates compression of the hourly wage distribution. However, the fixed effects estimation indicates only wage growth in the first quintile without a compression effect.

$<<$ Table 11 about here $>>$

\footnotetext{
${ }^{20}$ Source: FDZ der Statistischen Ämter des Bundes und der Länder, Verdienststrukturerhebung, 2014.
} 


\section{Conclusion}

This paper has assessed the short-term effects of Germany's minimum wage reform on the distribution of hourly wages, monthly earnings, and working hours. In January 2015, Germany introduced its first statutory minimum wage, with only a few legal exemptions. The new minimum wage was set at $€ 8.50$, exceeding the hourly wages of more than 10 percent of all eligible employees in 2014. We analyzed the implications of this major labor market intervention, which are particularly interesting in a G7 country like Germany.

As regards the reform's main aim, which was to increase hourly wages at the bottom of the wage distribution, our empirical data suggest that it was effective. In the low-wage segment, the descriptive analyses show an acceleration of wage growth in the first year after the reform and a clear reduction of wage inequality. A difference-in-differences analysis relying on the regional variation in treatment intensity as a source of identification provides supporting evidence. We find sizable positive treatment effects for the bottom quintile of the region-specific wage distributions. Yet our results show that the minimum wage reform has been more effective in altering contractual hourly wages than actual hourly wages. Furthermore, the reform did not improve monthly earnings for employees with low-paid jobs. This is due to the fact that although wages increased at the bottom of the wage distribution, most of those employees experienced an equiproportionate reduction of working hours. This finding is very similar to those from studies carried out in the United States (Neumark et al., 2004).

Moreover, about seven percent of eligible employees still earned below the new wage floor in the first half of 2015. This might be due in part to measurement error in the underlying survey data and to the limited number of observations in some regions. However, the estimates also suggest another plausible explanation, which is simple non-compliance. Moreover, since this study only looks at the first six months after the introduction of the minimum wage, the process of implementing the wage floor was probably not yet completed, and employers and authorities were still making some adjustments. In 2015, checks by administrative officials to ensure compliance with the regulations were also relatively rare. Furthermore, it is argued that the lack of time-keeping and documentation regulations for employers posed problems for monitoring and enforcement.

Our analysis provides two important lessons for policymakers in Germany and in other countries as well. First, because of adjustments in working hours, an hourly minimum wage does not necessarily improve monthly earnings for employees with low pay, nor does it reduce 
their dependence on social transfers. A more effective instrument for achieving these objectives might be a monthly minimum wage. Second, a minimum wage can only produce its full desired effect if it is well-executed. In the German case, the short-run wage adjustments have not been high enough to reach the wage floor stipulated by law across the board. On the one hand, this is because high rates of non-compliance have hampered the aim of reducing the number of working poor. This is especially relevant in the area of flexible jobs such as "mini-jobs" that entail low bureaucratic costs and high potential for employers to circumvent the wage floor. On the other hand, non-compliance could also dampen reactions on the labor market. This is potentially part of the the reason why Garloff (2016), Bossler and Gerner (2016) and Caliendo et al. (2017) report that the minimum-wage reform has had no or only minor negative employment effects in the short run. 


\section{References}

Amlinger, M., Bispinck, R. and Schulten, T. (2016). Ein Jahr Mindestlohn in Deutschland - Erfahrungen und Perspektiven. WSI-Report, 28.

Antonczyk, D., Fitzenberger, B. and Sommerfeld, K. (2010). Rising Wage Inequality, the Decline of Collective Bargaining, and the Gender Wage Gap. Labour Economics, 5 (17), 835-847.

Autor, D. H., Manning, A. and Smith, C. L. (2016). The Contribution of the Minimum Wage to US Wage Inequality over Three Decades: A Reassessment. American Economic Journal: Applied Economics, 8 (1), 58-99.

Bach, S., Corneo, G. and Steiner, V. (2009). From Bottom to Top: The Entire Income Distribution in Germany, 1992-2003. Review of Income and Wealth, 2 (55), 303-330.

Baumgarten, D., Geishecker, I. and Görg, H. (2013). Offshoring, Tasks, and the SkillWage Pattern. European Economic Review, 1 (61), 132-152.

BBSR (2016). Bundesinstitut für Bau- Stadt- und Raumforschung - INKAR: Indikatoren und Karten zur Raum und Stadtenwicklung.

Bossler, M. and Gerner, H.-D. (2016). Employment Effects of the New German Minimum Wage, IAB Discussion Paper 10/2016, Nuremberg.

Brautzsch, H.-U. and Schultz, B. (2013). Im Fokus: Mindestlohn von 8,50 Euro: Wie viele verdienen weniger, und in welchen Branchen arbeiten sie? IWH, Wirtschaft im Wandel, 19 (3), $53-56$.

Brenke, K. (2014). Mindestlohn: Zahl der anspruchsberechtigten Arbeitnehmer wird weit unter fünf Millionen liegen. DIW-Wochenbericht, 81 (5), 71-77.

Brown, C. (1999). Minimum Wages, Employment, and the Distribution of Income. Handbook of Labor Economics, 3 (Part B), 2101-2163.

Caliendo, M., Fedorets, A., Preuss, M., Schröder, C. and Wittbrodt, L. (2017). The Short-Run Employment Effects of the German Minimum Wage Reform, IZA Discussion Paper No. 11190, Bonn.

-, KÜnn, S. and Uhlendroff, A. (2016). Earnings Exemptions for Unemployed Workers: The Relationship between Marginal Employment, Unemployment Duration and Job Quality. Labour Economics, 42, 177-193.

CARD, D. (1992a). Do Minimum Wages Reduce Employment? A Case Study of California, 1987-89. Industrial and Labor Relations Review, 46 (1), 38-54.

- (1992b). Using Regional Variation in Wages to Measure the Effects of the Federal Minimum Wage. Industrial and Labor Relations Review, 46 (1), 22-37.

-, Heining, J. and Kline, P. (2013). Workplace Heterogeneity and the Rise of West German Wage Inequality. Quarterly Journal of Economics, 3 (128), 967-1015.

- and Krueger, A. B. (1992). Minimum Wages and Employment: A Case Study of the FastFood Industry in New Jersey and Pennsylvania. The American Economic Review, 84 (4), $772-93$.

Corneo, G. (2015). Earnings Inequality in Germany and Its Implications. Economic and Political Studies, 3 (2), 60.

Destatis (2015). Verdiensterhebung 2015. 
Destatis (2016). 4 Millionen Jobs vom Mindestlohn betroffen, Statistisches Bundesamt press release from April 62016 - 121/16.

Deutscher Bundestag (2016a). Finanzkontrolle Schwarzarbeit - Kontrolle von Mindestlöhnen 2015, Drucksache.

Deutscher Bundestag (2016b). Kontrolle der Einhaltung des gesetzlichen Mindestlohns, Drucksache.

Dickens, R. and Manning, A. (2004a). Has the National Minimum Wage Reduced UK Wage Inequality? Journal of the Royal Statistical Society: Series A, 167 (4), 613-626.

- and - (2004b). Spikes and Spill-Overs: The Impact of the National Minimum Wage on the Wage Distribution in a Low-Wage Sector. Economic Journal, 114 (494), 95-101.

DiNardo, J., Fortin, N. M. and Lemieux, T. (1996). Labor Market Institutions and the Distribution of Wages, 1973-1992: A Semiparametric Approach. Econometrica, 64 (5), 10011044.

Dolton, P., Bondibene, C. R. and Stops, M. (2015). Identifying the Employment Effect of Invoking and Changing the Minimum Wage: A Spatial Analysis of the UK. Labour Economics, 37, 54-76.

—, - and Wadsworth, J. (2012). Employment, Inequality and the UK National Minimum Wage over the Medium-Term. Oxford Bulletin of Economics and Statistics, 74 (1), 78-106.

Dube, A., Lester, T. W. and Reich, M. (2010). Minimum Wage Effects Across State Borders: Estimates Using Contiguous Counties. The Review of Economics and Statistics, 92 (4), 945964.

Dustmann, C., Ludsteck, J. and Schönberg, U. (2009). Revisiting the German Wage Structure. The Quarterly Journal of Economics, 124 (2), 843-881.

Falck, O., Knabe, A., Mazat, A. and Wiederhold, S. (2013). Mindestlohn in Deutschland: Wie viele sind betroffen. ifo Schnelldienst, 66 (24), 68-73.

Fitzenberger, B. and Doerr, A. (2016). Konzeptionelle Lehren aus der ersten Evaluationsrunde der Branchenmindestlöhne in Deutschland. Journal for Labour Market Research, 49 (4), 329-347.

Frick, J. R. and Grabka, M. M. (2005). Item-Non-Response on Income Questions in Panel Surveys: Incidence, Imputation and the Impact on the Income Distribution. Allgemeines Statistisches Archiv (ASTA), 89 (1), 49-61.

- - - and Marcus, J. (2007). Editing and Multiple Imputation of Item-Non-Response in the 2002 Wealth Module of the German Socio-Economic Panel (SOEP), DIW Data Documentation, No. 18.

Frings, H. (2013). The Employment Effect of Industry-Specific, Collectively Bargained Minimum Wages. German Economic Review, 14 (3), 258-281.

Funke, M. and Niebuhr, A. (2005). Regional Geographic Research and Development Spillovers and Economic Growth: Evidence from West Germany. Regional Studies, 39 (1), 143-153.

Garloff, A. (2016). Side Effects of the New German Minimum Wage on (Un-)Employment. First Evidence from Regional Data, IAB Discussion Paper 31/2016, Nuremberg.

Kalina, T. and Weinkopf, C. (2014). Niedriglohnbeschäftigung 2012 und was ein gesetzlicher Mindestlohn von 8,50 Euro verändern könnte, IAQ-Report No. 02/2014.

Knabe, A., Sснӧв, R. and Thum, M. (2014). Der flächendeckende Mindestlohn. Perspektiven der Wirtschaftspolitik, 15 (2), 133-157. 
KöNig, M. and Möller, J. (2009). Impacts of Minimum Wages: A Microdata Analysis for the German Construction Sector. International Journal of Manpower, 30 (7), 716-741.

LEe, D. S. (1999). Wage Inequality in the United States during the 1980s: Rising Dispersion or Falling Minimum Wage. The Quarterly Journal of Economics, 114 (3), 977-1023.

Lesch, H., Mayer, A. and Schmid, L. (2014). Das deutsche Mindestlohngesetz. Eine erste ökonomische Bewertung. List Forum, 40 (1), 1-19.

Manning, A. (2003). Monopsony in Motion. Imperfect Competition in Labor Markets. Princeton University Press.

Metcalf, D. (2008). Why Has the British National Minimum Wage Had Little or No Impact on Employment? Journal of Industrial Relations, 50 (3), 489-512.

Mindestlohnkommission (2016a). Beschluss der Mindestlohnkommission nach $\S 9$ MiLoG, Berlin, June.

Mindestlohnkommission (2016b). Erster Bericht zu den Auswirkungen des gesetzlichen Mindestlohns, Bericht der Mindestlohnkommission an die Bundesregierung nach $\S 9$ Abs. 4 Mindestlohngesetz.

Neumark, D., Schweitzer, M. and Wascher, W. L. (2004). Minimum Wage Effects throughout the Wage Distribution. The Journal of Human Resources, 39 (2), 425-450.

- and Wascher, W. (1995). Minimum-Wage Effects on School and Work Transitions of Teenagers. American Economic Review, 85 (2), 244.

— and - (2001). Minimum Wages and Training Revisited. Journal of Labor Economics, 19 (3), $563-595$.

OECD (2015). Employment Outlook 2015. OECD Publishing.

SchröDER, C. (2014). Kosten und Nutzen von Mindestlöhnen, DIW Roundup 22.

SOEP v32 (2016). Data for Years 1984-2015, Version 32, SOEP, 2015.

Stewart, M. B. (2012). Wage Inequality, Minimum Wage Effects, and Spillovers. Oxford Economic Papers, 64 (4), 616-634.

Teulings, C. N. (2003). The Contribution of Minimum Wages to Increasing Wage Inequality. Economic Journal, 113 (490), 801-833.

vom Berge, P., Frings, H. and Paloyo, A. R. (2013). High-Impact Minimum Wages and Heterogeneous Regions, Ruhr Economic Papers 408.

-, Klingert, I., Becker, S., Lenhart, J., Trenkle, S. and Umkehrer, M. (2016). Mindestlohnbegleitforschung - Überprüfung der Ausnahmeregelung für Langzeitarbeitslose, IABForschungsbericht 8/2016.

Wagner, G. G., Frick, J. R. and Schupp, J. (2007). The German Socio-Economic Panel Study (SOEP) - Scope, Evolution and Enhancements. Journal of Applied Social Science Studies, 127, 139-169. 


\section{Tables and Figures}

Table 1: Observations per year under imposition of sample restrictions

\begin{tabular}{lcccc}
\hline & 2013 & 2014 & 2015 & Total \\
\hline SOEP v32 & 30,777 & 27,237 & 25,288 & 83,302 \\
w/o non-eligible & 15,699 & 13,991 & 12,942 & 42,632 \\
w/o sector-specific MW & 13,085 & 11,857 & 10,745 & 35,687 \\
w/o small regions (Sample 1) & 12,944 & 11,739 & 10,643 & 35,326 \\
w/o non-consecutive biannual wage info & 6,054 & 6,173 & 6,156 & 18,383 \\
w/o lacking individual info (Sample 2) & 5,965 & 6,074 & 6,059 & 18,098 \\
\hline
\end{tabular}

Notes: SOEP v32, own calculations.

Table 2: Sen index

\begin{tabular}{lcccc}
\hline & Sen & Head count & Gini poor & Minimum wage gap \\
\hline Contractual hourly wage & & & \\
\hline 2013 mean & 2.580 & 9.087 & 10.167 & 1.844 \\
$95 \%$ CI & $(2.325-2.835)$ & $(8.274-9.899)$ & $(9.485-10.849)$ & $(1.656-2.032)$ \\
2014 mean & 2.621 & 9.262 & 10.098 & 1.876 \\
$95 \%$ CI & $(2.368-2.875)$ & $(8.492-10.032)$ & $(9.502-10.694)$ & $(1.684-2.067)$ \\
2015 mean & 1.894 & 6.836 & 10.118 & 1.337 \\
$95 \%$ CI & $(1.638-2.149)$ & $(6.079-7.592)$ & $(9.401-10.835)$ & $(1.146-1.529)$ \\
\hline \hline Actual hourly wage & & & & 3.132 \\
\hline 2013 mean & 4.362 & 13.221 & 12.193 & $(2.867-3.397)$ \\
$95 \%$ CI & $(4.004-4.720)$ & $(12.265-14.177)$ & $(11.495-12.891)$ & 2.912 \\
2014 mean & 4.083 & 12.299 & 12.478 & $(2.635-3.189)$ \\
$95 \%$ CI & $(3.706-4.461)$ & $(11.332-13.267)$ & $(11.790-13.167)$ & 2.240 \\
2015 mean & 3.165 & 9.779 & 12.271 & $(1.983-2.497)$ \\
$95 \%$ CI & $(2.822-3.508)$ & $(8.890-10.667)$ & $(11.583-12.960)$ & \\
\hline
\end{tabular}

Notes: SOEP v32 (Sample 1), own calculations. Weighted by individual frequency weights.

The Sen index and its components are measured in percent.

Confidence intervals are defined as the point estimate plus or minus 1.96 times the standard deviation of the bootstrap-estimator with 200 repetitions. 
Table 3: Socio-demographic characteristics: total and with contractual hourly wages below $€ 8.50$

\begin{tabular}{|c|c|c|c|c|}
\hline Share of: & & 2013 & 2014 & 2015 \\
\hline \multirow[t]{2}{*}{ East Germany } & Total & 0.19 & 0.19 & 0.18 \\
\hline & Wage $<€ 8.50$ & 0.36 & 0.32 & 0.28 \\
\hline \multirow[t]{2}{*}{ Female } & Total & 0.49 & 0.49 & 0.49 \\
\hline & Wage $<€ 8.50$ & 0.67 & 0.70 & 0.69 \\
\hline \multirow[t]{2}{*}{ German citizenship } & Total & 0.92 & 0.91 & 0.92 \\
\hline & Wage $<€ 8.50$ & 0.87 & 0.84 & 0.87 \\
\hline \multirow[t]{2}{*}{ Primary education } & Total & 0.26 & 0.25 & 0.23 \\
\hline & Wage $<€ 8.50$ & 0.41 & 0.38 & 0.38 \\
\hline \multirow{2}{*}{ Secondary education } & Total & 0.45 & 0.46 & 0.47 \\
\hline & Wage $<€ 8.50$ & 0.50 & 0.52 & 0.51 \\
\hline \multirow[t]{2}{*}{ Tertiary education } & Total & 0.29 & 0.30 & 0.30 \\
\hline & Wage $<€ 8.50$ & 0.09 & 0.10 & 0.11 \\
\hline \multirow[t]{2}{*}{ Married } & Total & 0.57 & 0.57 & 0.55 \\
\hline & Wage $<€ 8.50$ & 0.52 & 0.51 & 0.50 \\
\hline \multirow[t]{2}{*}{ Household with children aged below 16} & Total & 0.28 & 0.28 & 0.29 \\
\hline & Wage $<€ 8.50$ & 0.28 & 0.30 & 0.26 \\
\hline \multirow[t]{2}{*}{ Mean age } & Total & 43.22 & 43.56 & 43.79 \\
\hline & Wage $<€ 8.50$ & 41.83 & 40.93 & 42.69 \\
\hline
\end{tabular}

Notes: SOEP v32 (Sample 1), own calculations. 
Table 4: Difference-in-differences: OLS and FE for hourly wages (2014-2015)

\begin{tabular}{lcccc}
\hline & OLS & & $\mathrm{FE}$ & \\
& Coef. & p-value & Coef & p-value \\
\hline Contractual hourly wages & & & & \\
Base & $0.020^{* *}$ & 0.039 & 0.008 & 0.191 \\
Base + socio-demographics & $0.015^{*}$ & 0.089 & 0.006 & 0.299 \\
Base by quintiles: & & & & \\
Q1 & $0.064^{* *}$ & 0.016 & $0.066^{* * *}$ & 0.001 \\
Q2 & 0.017 & 0.247 & 0.003 & 0.816 \\
Q3 & -0.008 & 0.483 & -0.012 & 0.268 \\
Q4 & 0.015 & 0.112 & 0.002 & 0.788 \\
Q5 & 0.030 & 0.686 & 0.010 & 0.579 \\
Base + socio-demographics by quintiles & & & & \\
Q1 & $0.065^{* *}$ & 0.010 & $0.058^{* * *}$ & 0.004 \\
Q2 & 0.012 & 0.420 & 0.003 & 0.862 \\
Q3 & -0.015 & 0.206 & -0.012 & 0.259 \\
Q4 & 0.011 & 0.285 & 0.000 & 0.999 \\
Q5 & 0.016 & 0.820 & 0.014 & 0.452 \\
\hline Actual hourly wages & & & & \\
Base & $0.022^{* *}$ & 0.020 & 0.006 & 0.328 \\
Base + socio-demographics & $0.017^{*}$ & 0.054 & 0.005 & 0.454 \\
Base by quintiles: & & & & \\
Q1 & $0.073^{* * *}$ & 0.002 & $0.075 * * *$ & 0.000 \\
Q2 & 0.018 & 0.178 & 0.005 & 0.713 \\
Q3 & -0.011 & 0.382 & -0.016 & 0.151 \\
Q4 & 0.009 & 0.356 & -0.004 & 0.699 \\
Q5 & 0.037 & 0.613 & 0.012 & 0.558 \\
Base + socio-demographics by quintiles & & & & \\
Q1 & $0.074^{* * *}$ & 0.001 & $0.069^{* * *}$ & 0.001 \\
Q2 & 0.013 & 0.358 & 0.004 & 0.746 \\
Q3 & -0.019 & 0.163 & -0.017 & 0.138 \\
Q4 & 0.005 & 0.641 & -0.008 & 0.448 \\
Q5 & 0.022 & 0.752 & 0.016 & 0.456 \\
\hline & & & & \\
\hline
\end{tabular}

Notes: SOEP v32 (Sample 2), own calculations.

Significance levels: $* \mathrm{p}<0.1, * * \mathrm{p}<0.05, * * * \mathrm{p}<0.01$

Specifications with include controls for gender, age, German citizenship, presence of children aged below 16 in the household, marital status, and two-periods lagged regional GDP. 
Table 5: Difference-in-differences: OLS and FE for gross monthly earnings, contractual and actual working hours (2014-2015)

\begin{tabular}{lcccc}
\hline & $\begin{array}{c}\text { OLS } \\
\text { Coef. }\end{array}$ & p-value & Coef & p-value \\
\hline Monthly earnings & & & & \\
Base + socio-demographics & 0.010 & 0.448 & -0.001 & 0.892 \\
Base + socio-demographics by quintiles & & & & \\
Q1 & 0.003 & 0.927 & 0.023 & 0.242 \\
Q2 & 0.001 & 0.963 & -0.011 & 0.425 \\
Q3 & -0.015 & 0.220 & -0.003 & 0.760 \\
Q4 & 0.002 & 0.853 & -0.008 & 0.371 \\
Q5 & 0.048 & 0.561 & 0.012 & 0.363 \\
\hline Contractual hours & & & & \\
Base + socio-demographics & -0.005 & 0.465 & -0.007 & 0.136 \\
Base + socio-demographics by quintiles & & & & \\
Q1 & $-0.062^{* *}$ & 0.017 & $-0.035^{* *}$ & 0.031 \\
Q2 & -0.011 & 0.502 & -0.014 & 0.273 \\
Q3 & 0.000 & 0.999 & 0.009 & 0.241 \\
Q4 & -0.009 & 0.318 & -0.008 & 0.148 \\
Q5 & 0.032 & 0.284 & -0.002 & 0.903 \\
\hline Actual hours & & & & \\
Base + socio-demographics & -0.005 & 0.464 & -0.003 & 0.471 \\
Base + socio-demographics by quintiles & & & & \\
Q1 & $-0.048^{*}$ & 0.069 & $-0.031^{*}$ & 0.061 \\
Q2 & -0.014 & 0.390 & -0.017 & 0.120 \\
Q3 & -0.005 & 0.683 & 0.009 & 0.302 \\
Q4 & -0.004 & 0.684 & -0.002 & 0.809 \\
Q5 & 0.036 & 0.260 & 0.011 & 0.549 \\
\hline
\end{tabular}

Notes: SOEP v32 (Sample 2), own calculations.

Significance levels: $* \mathrm{p}<0.1, * * \mathrm{p}<0.05, * * * \mathrm{p}<0.01$

Specifications with include controls for gender, age, German citizenship, presence of children aged below 16 in the household, marital status, and two-periods lagged regional GDP. 
Table 6: Placebo regressions for hourly wages, gross monthly earnings and working hours (20132014)

\begin{tabular}{lcccc}
\hline & OLS & & $\mathrm{FE}$ & \\
& Coef. & p-value & Coef & p-value \\
\hline Contractual hourly wages & & & & \\
Base + socio-demographics & 0.005 & 0.543 & -0.011 & 0.110 \\
Base + socio-demographics by quintiles & & & & \\
Q1 & $-0.037^{*}$ & 0.082 & -0.029 & 0.221 \\
Q2 & 0.008 & 0.517 & -0.006 & 0.617 \\
Q3 & 0.009 & 0.547 & 0.008 & 0.463 \\
Q4 & -0.012 & 0.339 & $-0.024^{* *}$ & 0.024 \\
Q5 & -0.044 & 0.395 & -0.012 & 0.669 \\
\hline Actual hourly wages & & & & \\
Base + socio-demographics & 0.008 & 0.366 & -0.003 & 0.691 \\
Base + socio-demographics by quintiles & & & & \\
Q1 & -0.030 & 0.174 & -0.018 & 0.448 \\
Q2 & $0.021^{*}$ & 0.090 & 0.009 & 0.502 \\
Q3 & 0.007 & 0.640 & 0.008 & 0.484 \\
Q4 & -0.017 & 0.189 & $-0.024^{* *}$ & 0.037 \\
Q5 & -0.050 & 0.283 & -0.004 & 0.884 \\
\hline Monthly earnings & & & & \\
Base + socio-demographics & 0.002 & 0.886 & -0.012 & 0.118 \\
Base + socio-demographics by quintiles & & & & \\
Q1 & -0.020 & 0.443 & -0.030 & 0.200 \\
Q2 & -0.015 & 0.294 & -0.015 & 0.258 \\
Q3 & 0.014 & 0.455 & 0.005 & 0.670 \\
Q4 & -0.028 & 0.181 & $-0.034^{*}$ & 0.058 \\
Q5 & -0.033 & 0.579 & -0.013 & 0.535 \\
\hline Contractual hourls & & & & \\
Base + socio-demographics & -0.003 & 0.724 & -0.001 & 0.802 \\
Base + socio-demographics by quintiles & & & & \\
Q1 & 0.017 & 0.451 & -0.001 & 0.952 \\
Q2 & $-0.023^{* *}$ & 0.040 & -0.009 & 0.266 \\
Q3 & 0.005 & 0.714 & -0.003 & 0.746 \\
Q4 & -0.016 & 0.313 & -0.009 & 0.515 \\
Q5 & 0.011 & 0.676 & -0.002 & 0.916 \\
\hline Actual hours & & & & \\
Base + socio-demographics & -0.006 & 0.590 & -0.006 & 0.314 \\
Base + socio-demographics by quintiles & & & & \\
Q1 & -0.014 & 0.583 & -0.018 & 0.219 \\
Q2 & $-0.021^{*}$ & 0.069 & -0.014 & 0.171 \\
Q3 & 0.010 & 0.480 & 0.000 & 0.985 \\
Q4 & -0.009 & 0.528 & -0.007 & 0.588 \\
Q5 & 0.011 & 0.737 & -0.003 & 0.880 \\
\hline & & & &
\end{tabular}

Notes: SOEP v32 (Sample 2), own calculations.

Significance levels: ${ }^{*} \mathrm{p}<0.1,{ }^{* *} \mathrm{p}<0.05,{ }^{* * *} \mathrm{p}<0.01$

Specifications with include controls for gender, age, German citizenship, presence of children aged below 16 in the household, marital status, and two-periods lagged regional GDP. 
Table 7: Sen index: sensitivity to measurement errors

\begin{tabular}{|c|c|c|c|c|}
\hline & Sen & Head count & Gini poor & Minimum wage gap \\
\hline \multicolumn{5}{|l|}{ Contractual hourly wage } \\
\hline \multicolumn{5}{|l|}{$\mathrm{MW}=0.95 \mathrm{x} € 8.50=€ 8.075$} \\
\hline $\begin{array}{l}2013 \text { mean } \\
95 \% \text { CI }\end{array}$ & $\begin{array}{c}2.074 \\
(1.849-2.298)\end{array}$ & $\begin{array}{c}7.439 \\
(6.722-8.156)\end{array}$ & $\begin{array}{c}9.691 \\
(9.022-10.359)\end{array}$ & $\begin{array}{c}1.498 \\
(1.332-1.664)\end{array}$ \\
\hline $\begin{array}{l}2014 \text { mean } \\
95 \% \text { CI }\end{array}$ & $\begin{array}{c}2.093 \\
(1.870-2.315)\end{array}$ & $\begin{array}{c}7.493 \\
(6.749-8.237)\end{array}$ & $\begin{array}{c}9.488 \\
(8.855-10.122)\end{array}$ & $\begin{array}{c}1.526 \\
(1.359-1.694)\end{array}$ \\
\hline $\begin{array}{l}2015 \text { mean } \\
95 \% \text { CI }\end{array}$ & $\begin{array}{c}1.501 \\
(1.278-1.724)\end{array}$ & $\begin{array}{c}5.434 \\
(4.757-6.110)\end{array}$ & $\begin{array}{c}9.647 \\
(8.949-10.346)\end{array}$ & $\begin{array}{c}1.082 \\
(0.912-1.251)\end{array}$ \\
\hline \multicolumn{5}{|l|}{$\mathrm{MW}=0.90 \mathrm{x} € 8.50=€ 7.65$} \\
\hline $\begin{array}{l}2013 \text { mean } \\
95 \% \text { CI }\end{array}$ & $\begin{array}{c}1.676 \\
(1.477-1.875)\end{array}$ & $\begin{array}{c}6.362 \\
(5.713-7.012)\end{array}$ & $\begin{array}{c}9.444 \\
(8.810-10.078)\end{array}$ & $\begin{array}{c}1.187 \\
(1.040-1.335)\end{array}$ \\
\hline $\begin{array}{l}2014 \text { mean } \\
95 \% \text { CI }\end{array}$ & $\begin{array}{c}1.689 \\
(1.495-1.882)\end{array}$ & $\begin{array}{c}6.429 \\
(5.720-7.137)\end{array}$ & $\begin{array}{c}9.076 \\
(8.466-9.687)\end{array}$ & $\begin{array}{c}1.216 \\
(1.073-1.359)\end{array}$ \\
\hline $\begin{array}{l}2015 \text { mean } \\
95 \% \text { CI }\end{array}$ & $\begin{array}{c}1.190 \\
(0.997-1.383)\end{array}$ & $\begin{array}{c}4.461 \\
(3.827-5.095)\end{array}$ & $\begin{array}{c}9.157 \\
(8.535-9.780)\end{array}$ & $\begin{array}{c}0.860 \\
(0.713-1.008)\end{array}$ \\
\hline \multicolumn{5}{|l|}{ Actual hourly wage } \\
\hline $\begin{array}{l}2013 \text { mean } \\
95 \% \text { CI }\end{array}$ & $\begin{array}{c}3.676 \\
(3.350-4.002)\end{array}$ & $\begin{array}{c}11.387 \\
(10.495-12.280)\end{array}$ & $\begin{array}{c}11.844 \\
(11.131-12.558)\end{array}$ & $\begin{array}{c}2.640 \\
(2.399-2.881)\end{array}$ \\
\hline $\begin{array}{l}2014 \text { mean } \\
95 \% \text { CI }\end{array}$ & $\begin{array}{c}3.412 \\
(3.073-3.750)\end{array}$ & $\begin{array}{c}10.317 \\
(9.419-11.216)\end{array}$ & $\begin{array}{c}12.121 \\
(11.407-12.835)\end{array}$ & $\begin{array}{c}2.459 \\
(2.209-2.710)\end{array}$ \\
\hline $\begin{array}{l}2015 \text { mean } \\
95 \% \text { CI }\end{array}$ & $\begin{array}{c}2.614 \\
(2.308-2.921) \\
\end{array}$ & $\begin{array}{c}8.034 \\
(7.219-8.848) \\
\end{array}$ & $\begin{array}{c}11.838 \\
(11.175-12.502)\end{array}$ & $\begin{array}{c}1.887 \\
(1.654-2.119) \\
\end{array}$ \\
\hline \multicolumn{5}{|l|}{$\mathrm{MW}=0.90 \mathrm{x} € 8.50=€ 7.65$} \\
\hline $\begin{array}{l}2013 \text { mean } \\
95 \% \text { CI }\end{array}$ & $\begin{array}{c}3.067 \\
(2.773-3.362)\end{array}$ & $\begin{array}{c}9.787 \\
(8.970-10.604)\end{array}$ & $\begin{array}{c}11.631 \\
(10.904-12.357)\end{array}$ & $\begin{array}{c}2.183 \\
(1.967-2.400)\end{array}$ \\
\hline $\begin{array}{l}2014 \text { mean } \\
95 \% \text { CI }\end{array}$ & $\begin{array}{c}2.853 \\
(2.552-3.153)\end{array}$ & $\begin{array}{c}8.850 \\
(8.027-9.672)\end{array}$ & $\begin{array}{c}11.791 \\
(11.089-12.492)\end{array}$ & $\begin{array}{c}2.051 \\
(1.827-2.275)\end{array}$ \\
\hline $\begin{array}{l}2015 \text { mean } \\
95 \% \mathrm{CI}\end{array}$ & $\begin{array}{c}2.164 \\
(1.891-2.437)\end{array}$ & $\begin{array}{c}6.788 \\
(6.020-7.556)\end{array}$ & $\begin{array}{c}11.354 \\
(10.747-11.961)\end{array}$ & $\begin{array}{c}1.572 \\
(1.364-1.780)\end{array}$ \\
\hline
\end{tabular}

Notes: SOEP v32 (Sample 1), own calculations. Weighted by individual frequency weights.

The Sen index and its components are measured in percent.

Confidence intervals are defined as the point estimate plus or minus 1.96 times the standard deviation of the bootstrap-estimator with 200 repetitions. 
Table 8: Sen index: sensitivity to outliers and item non-response

\begin{tabular}{lcccc}
\hline & Sen & Head count & Gini poor & Minimum wage gap \\
\hline Contractual hourly wage & & & & \\
2014 mean & 2.621 & 9.262 & 10.098 & 1.876 \\
$95 \%$ CI & $(2.368-2.875)$ & $(8.492-10.032)$ & $(9.502-10.694)$ & $(1.684-2.067)$ \\
2015 mean & 1.894 & 6.836 & 10.118 & 1.337 \\
$\quad 95 \%$ CI & $(1.638-2.149)$ & $(6.079-7.592)$ & $(9.401-10.835)$ & $(1.146-1.529)$ \\
$\ldots$ with imputed wages & & & & \\
2014 mean & 3.724 & 10.474 & 14.573 & 2.573 \\
$95 \%$ CI & $(3.309-4.140)$ & $(9.627-11.321)$ & $(13.046-16.100)$ & $(2.284-2.861)$ \\
2015 mean & 3.157 & 8.021 & 17.308 & 2.139 \\
$95 \%$ CI & $(2.760-3.553)$ & $(7.253-8.788)$ & $(15.340-19.276)$ & $(1.863-2.414)$ \\
\hline
\end{tabular}

Notes: SOEP v32 (Sample 1), own calculations. Weighted by individual frequency weights.

The Sen index and its components are measured in percent.

Confidence intervals are defined as the point estimate plus or minus 1.96 times the standard deviation of the bootstrap-estimator with 200 repetitions.

Table 9: Difference-in-differences: OLS and FE for alternative calculations of hourly wages (20142015)

\begin{tabular}{lcccc}
\hline & $\begin{array}{c}\text { OLS } \\
\text { Coef. }\end{array}$ & p-value & $\begin{array}{c}\text { FE } \\
\text { Coef }\end{array}$ & p-value \\
\hline $\begin{array}{l}\text { Contractual hourly wages with imputed wages } \\
\text { Base + socio-demographics }\end{array}$ & $0.015^{*}$ & 0.089 & 0.006 & 0.299 \\
Base + socio-demographics by quintiles: & & & & \\
Q1 & $0.065^{* *}$ & 0.010 & $0.058^{* * *}$ & 0.004 \\
Q2 & 0.012 & 0.420 & 0.003 & 0.862 \\
Q3 & -0.015 & 0.206 & -0.012 & 0.259 \\
Q4 & 0.011 & 0.285 & 0.000 & 0.999 \\
Q5 & 0.016 & 0.820 & 0.014 & 0.452 \\
\hline
\end{tabular}

Notes: SOEP v32 (Sample 2), own calculations.

Significance levels: $* \mathrm{p}<0.1,{ }^{* *} \mathrm{p}<0.05, * * * \mathrm{p}<0.01$

Specifications with include controls for gender, age, German citizenship, presence of children aged below 16 in the household, marital status, and two-periods lagged regional GDP. 
Table 10: Difference-in-differences: OLS for hourly wages in Sample 2 and Sample 1 (2014-2015)

\begin{tabular}{lcccc}
\hline & $\begin{array}{c}\text { Sample } 2 \\
\text { Coef. }\end{array}$ & p-value & $\begin{array}{c}\text { Sample } 1 \\
\text { Coef }\end{array}$ & p-value \\
\hline Contractual hourly wages & & & & \\
Base + socio-demographics & $0.015^{*}$ & 0.089 & 0.004 & 0.657 \\
Base + socio-demographics by quintiles & & & & \\
Q1 & $0.065^{* *}$ & 0.010 & $0.056^{* * *}$ & 0.009 \\
Q2 & 0.012 & 0.420 & 0.018 & 0.195 \\
Q3 & -0.015 & 0.206 & $-0.021^{*}$ & 0.072 \\
Q4 & 0.011 & 0.285 & 0.003 & 0.768 \\
Q5 & 0.016 & 0.820 & -0.009 & 0.808 \\
\hline
\end{tabular}

Notes: SOEP v32 (Sample 2), own calculations.

Significance levels: ${ }^{*} \mathrm{p}<0.1,{ }^{* *} \mathrm{p}<0.05,{ }^{* * *} \mathrm{p}<0.01$

Specifications with include controls for gender, age, German citizenship, presence of children aged below 16 in the household, marital status, and two-periods lagged regional GDP.

Table 11: Difference-in-differences: OLS and FE for hourly wages using the Kaitz index from VSE-2014 (2014-2015)

\begin{tabular}{lcccc}
\hline & $\begin{array}{c}\text { OLS } \\
\text { Coef. }\end{array}$ & p-value & $\begin{array}{c}\text { FE } \\
\text { Coef }\end{array}$ & p-value \\
\hline $\begin{array}{l}\text { Contractual hourly wages } \\
\text { Base + socio-demographics }\end{array}$ & 0.021 & 0.400 & -0.002 & 0.901 \\
Base + socio-demographics by quintiles & & & & \\
Q1 & $0.166^{* *}$ & 0.029 & $0.106^{*}$ & 0.063 \\
Q2 & 0.027 & 0.426 & -0.013 & 0.714 \\
Q3 & $-0.048^{*}$ & 0.074 & -0.030 & 0.238 \\
Q4 & 0.018 & 0.494 & -0.024 & 0.331 \\
Q5 & 0.025 & 0.879 & -0.015 & 0.726 \\
\hline
\end{tabular}

Notes: SOEP v32 (Sample 2), own calculations.

Significance levels: ${ }^{*} \mathrm{p}<0.1,{ }^{* *} \mathrm{p}<0.05,{ }^{* * *} \mathrm{p}<0.01$

Specifications with include controls for gender, age, German citizenship, presence of children aged below 16 in the household, marital status, and two-periods lagged regional GDP. 
Figure 1: Pen's parades for contractual and actual gross hourly wages (2013 to 2015)

Contractual hourly wages
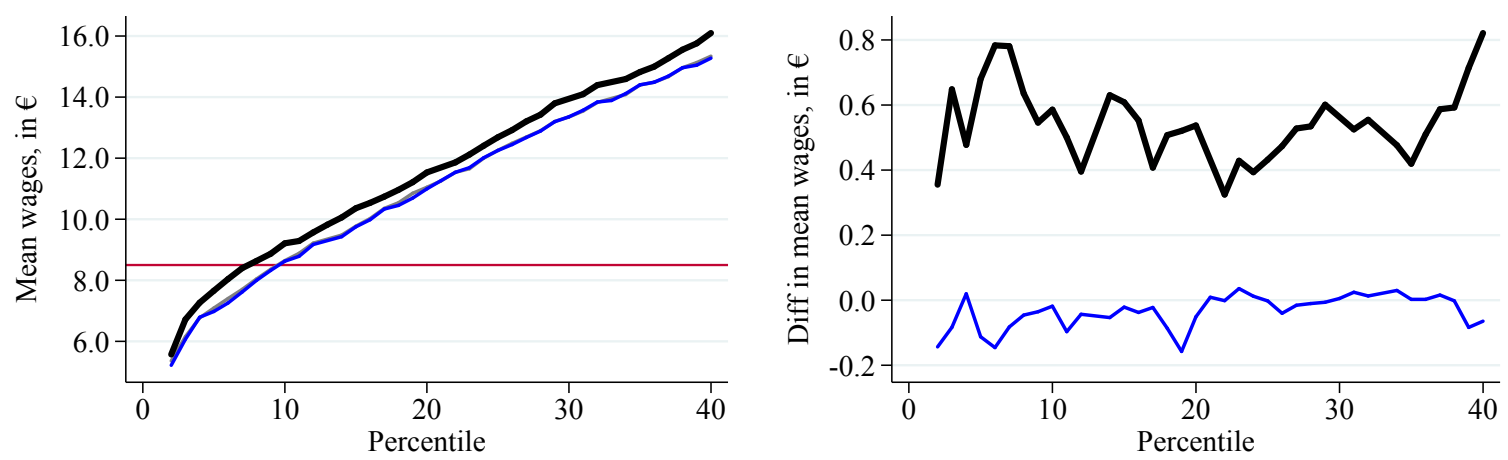

Actual hourly wages
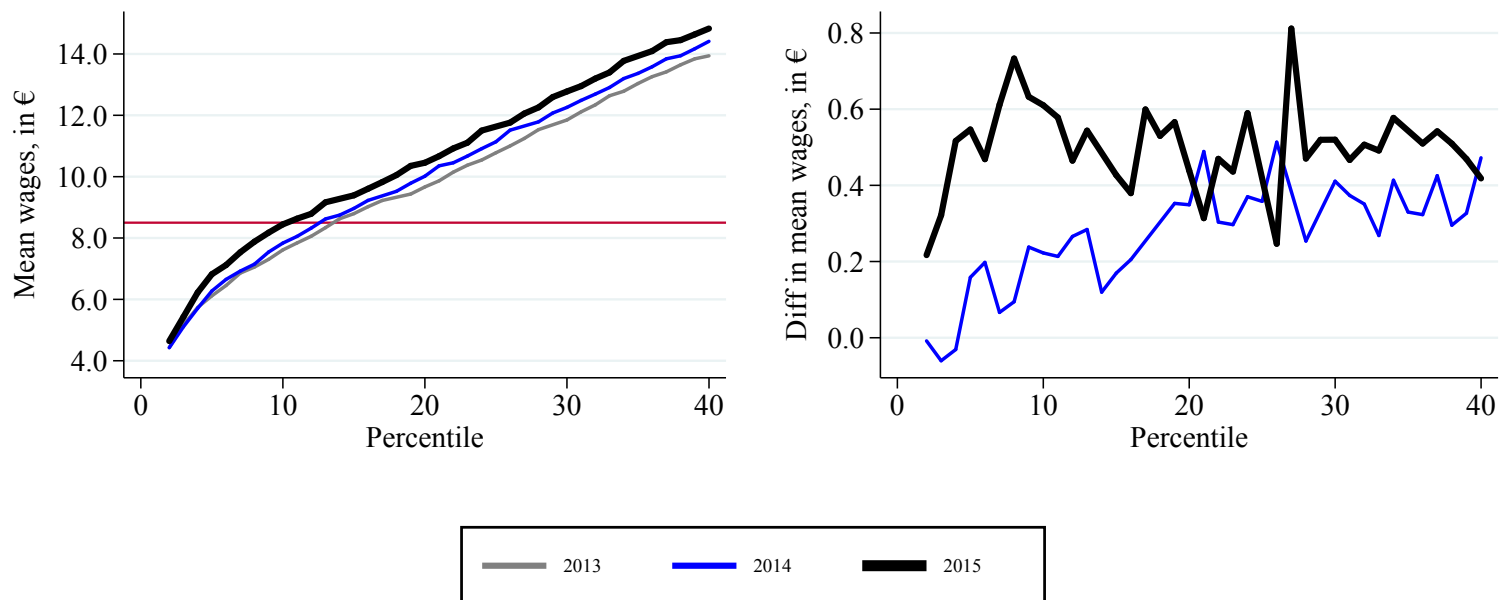

Notes: SOEP v32 (Sample 1), own calculations. Weighted by individual frequency weights. 
Figure 2: Pen's parades for gross monthly earnings (2013 to 2015)
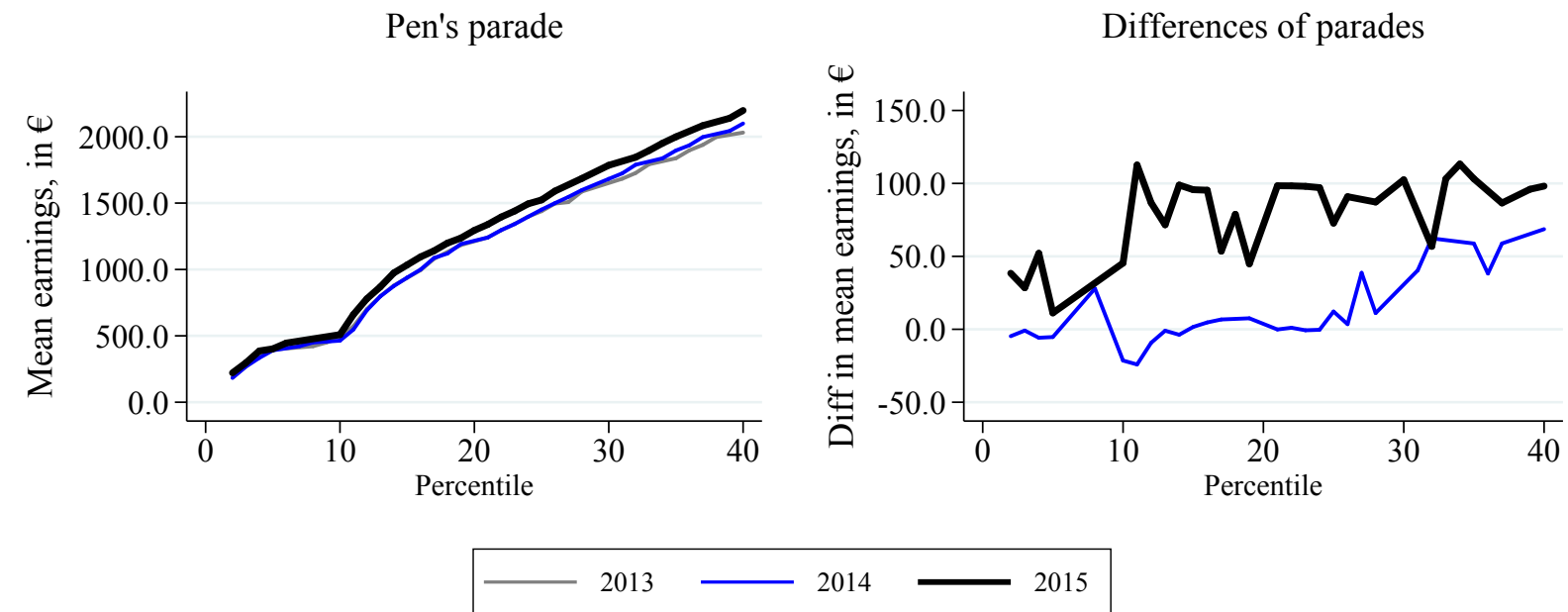

Notes: SOEP v32 (Sample 1), own calculations. Weighted by individual frequency weights.

Figure 3: Regional intensity of treatment, SOEP 2013

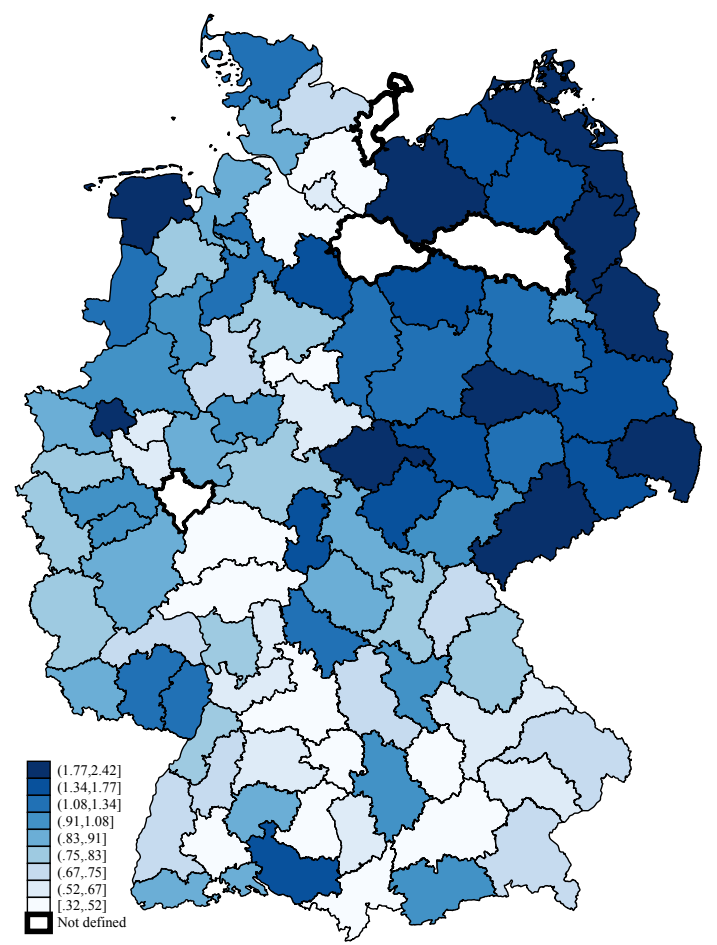

Notes: SOEP v32 (Sample 1), own calculations. 
Figure 4: Evolution of hourly wages by year and regional treatment intensity

(a) Mean hourly wages

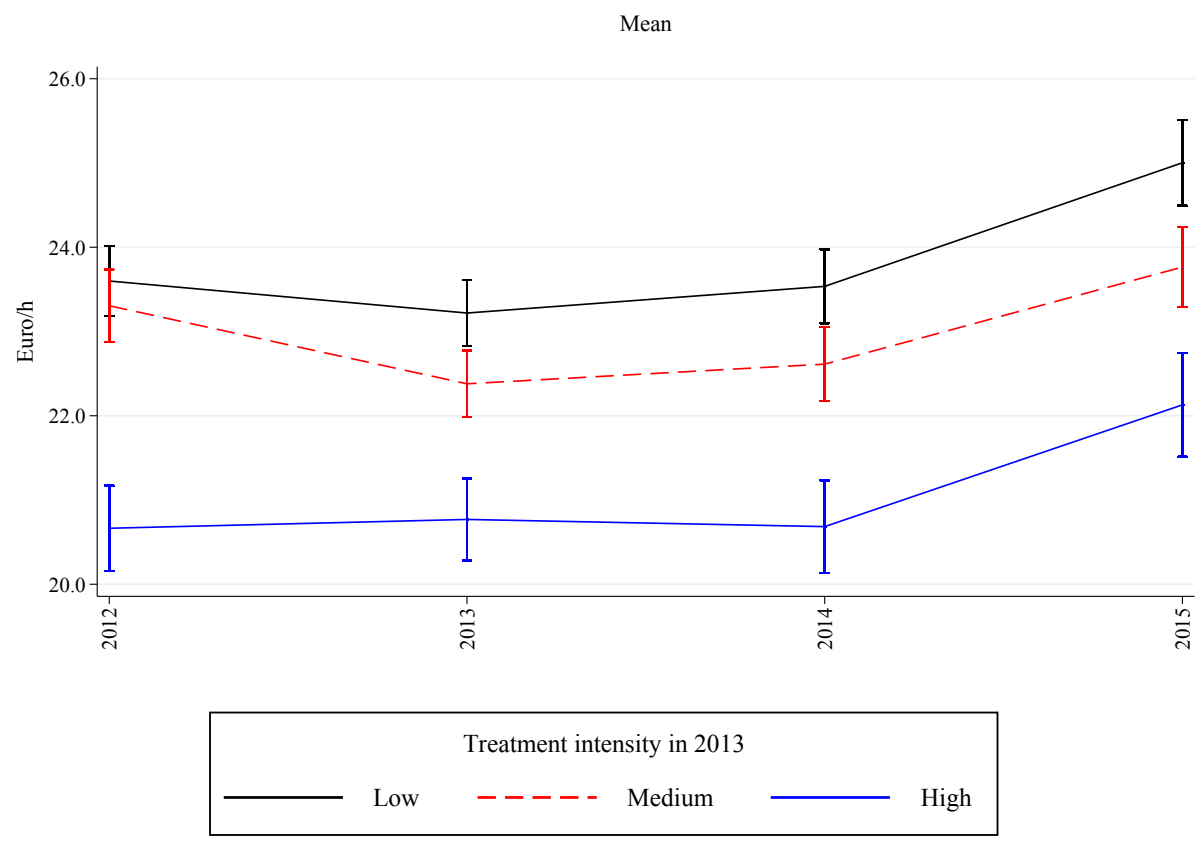

(b) Quintiles 1-3 of hourly wages

Q 1

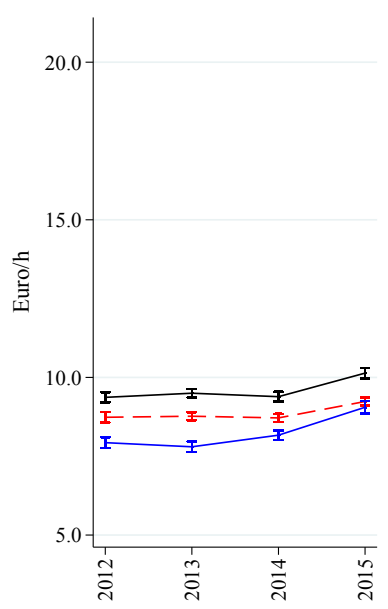

Q 2

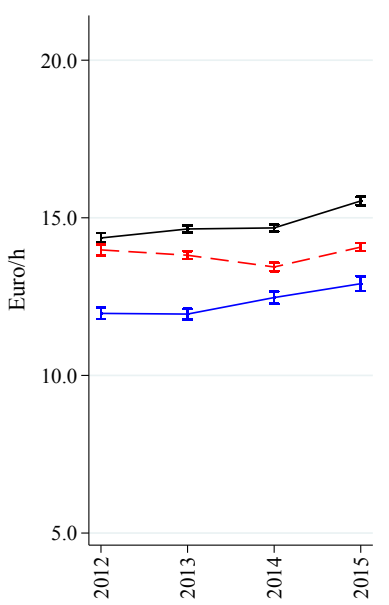

Q 3

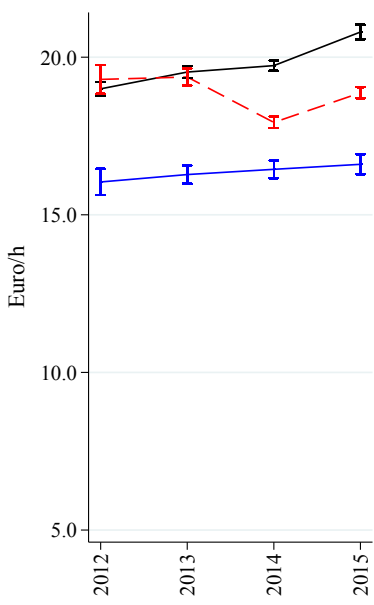

Treatment intensity in 2013

Low

Medium

Notes: SOEP v32 (Sample 2), own calculations.

Whiskers denote $95 \%$ bootstrap confidence intervals (200 repetitions). 


\section{A Supplementary Tables and Figures}

Table A.1: Sen index, by labor market status for contractual hourly wages

\begin{tabular}{lcccc}
\hline & Sen & Head count & Gini poor & Minimum wage gap \\
\hline Full-time employed & & & & \\
2013 mean & 1.682 & 7.263 & 8.146 & 1.187 \\
$\quad 95 \%$ CI & $(1.459-1.904)$ & $(6.312-8.214)$ & $(7.437-8.856)$ & $(1.026-1.347)$ \\
2014 mean & 1.485 & 6.187 & 8.702 & 1.037 \\
$\quad 95 \%$ CI & $(1.234-1.735)$ & $(5.408-6.966)$ & $(7.683-9.721)$ & $(0.853-1.220)$ \\
2015 mean & 1.262 & 4.723 & 10.387 & 0.861 \\
$\quad 95 \%$ CI & $(0.959-1.565)$ & $(3.892-5.555)$ & $(9.052-11.722)$ & $(0.642-1.080)$ \\
\hline Part-time employed & & & & \\
2013 mean & 1.750 & 6.517 & 9.657 & 1.240 \\
$95 \%$ CI & $(1.337-2.162)$ & $(5.308-7.726)$ & $(7.901-11.413)$ & $(0.934-1.546)$ \\
2014 mean & 1.684 & 7.460 & 8.446 & 1.151 \\
$95 \%$ CI & $(1.269-2.098)$ & $(5.952-8.969)$ & $(6.887-10.005)$ & $(0.855-1.447)$ \\
2015 mean & 1.364 & 5.892 & 8.165 & 0.961 \\
$95 \%$ CI & $(0.927-1.800)$ & $(4.293-7.491)$ & $(6.602-9.727)$ & $(0.635-1.287)$ \\
\hline Mini-jobs & & & & \\
2013 mean & 13.473 & 37.979 & 11.916 & 10.158 \\
$95 \%$ CI & $(11.395-15.552)$ & $(33.026-42.932)$ & $(11.059-12.774)$ & $(8.492-11.824)$ \\
2014 mean & 15.355 & 44.705 & 10.981 & 11.735 \\
$95 \%$ CI & $(13.451-17.259)$ & $(39.537-49.873)$ & $(10.185-11.777)$ & $(10.198-13.271)$ \\
2015 mean & 10.331 & 33.350 & 10.501 & 7.630 \\
$95 \%$ CI & $(8.713-11.950)$ & $(28.725-37.975)$ & $(9.482-11.519)$ & $(6.356-8.905)$ \\
\hline
\end{tabular}

Notes: SOEP v32 (Sample 1), own calculations.

The Sen index and its components are measured in percent.

Confidence intervals are defined as the point estimate plus or minus 1.96 times the standard deviation of the bootstrap-estimator with 200 repetitions. 
Table A.2: Sen index, by gender for contractual hourly wages

\begin{tabular}{ccccc}
\hline & Sen & Head count & Gini poor & Minimum wage gap \\
\hline Men & & & & \\
2013 mean & 1.626 & 5.885 & 9.812 & 1.162 \\
$95 \%$ CI & $(1.343-1.908)$ & $(4.922-6.848)$ & $(8.677-10.946)$ & $(0.956-1.369)$ \\
2014 mean & 1.444 & 5.369 & 9.637 & 1.026 \\
$95 \%$ CI & $(1.169-1.720)$ & $(4.492-6.246)$ & $(8.442-10.832)$ & $(0.823-1.228)$ \\
2015 mean & 1.274 & 4.213 & 11.074 & 0.908 \\
$95 \%$ CI & $(0.916-1.632)$ & $(3.299-5.127)$ & $(9.802-12.346)$ & $(0.633-1.183)$ \\
\hline Women & & & & \\
2013 mean & 3.500 & 12.179 & 10.312 & 2.502 \\
$95 \%$ CI & $(3.108-3.891)$ & $(10.997-13.360)$ & $(9.504-11.120)$ & $(2.208-2.796)$ \\
2014 mean & 3.841 & 13.306 & 10.264 & 2.758 \\
$95 \%$ CI & $(3.427-4.255)$ & $(12.007-14.604)$ & $(9.533-10.996)$ & $(2.442-3.075)$ \\
2015 mean & 2.519 & 9.514 & 9.610 & 1.776 \\
$95 \%$ CI & $(2.152-2.887)$ & $(8.272-10.757)$ & $(8.779-10.441)$ & $(1.506-2.045)$ \\
\hline
\end{tabular}

Notes: SOEP v32 (Sample 1), own calculations.

The Sen index and its components are measured in percent.

Confidence intervals are defined as the point estimate plus or minus 1.96 times the standard deviation of the bootstrap-estimator with 200 repetitions.

Table A.3: Sen index, by region for contractual hourly wages

\begin{tabular}{lcccc}
\hline & Sen & Head count & Gini poor & Minimum wage gap \\
\hline East Germany & & & & \\
2013 mean & 4.693 & 17.044 & 9.656 & 3.373 \\
$95 \%$ CI & $(3.952-5.434)$ & $(14.495-19.594)$ & $(8.575-10.736)$ & $(2.828-3.918)$ \\
2014 mean & 4.209 & 15.996 & 9.221 & 3.012 \\
$95 \%$ CI & $(3.472-4.946)$ & $(13.531-18.460)$ & $(8.244-10.198)$ & $(2.446-3.578)$ \\
2015 mean & 2.600 & 10.410 & 9.536 & 1.776 \\
$95 \%$ CI & $(1.879-3.320)$ & $(8.472-12.348)$ & $(7.832-11.239)$ & $(1.262-2.290)$ \\
\hline West Germany & & & & \\
2013 mean & 2.076 & 7.195 & 10.429 & 1.480 \\
$95 \%$ CI & $(1.819-2.334)$ & $(6.437-7.954)$ & $(9.540-11.319)$ & $(1.290-1.670)$ \\
2014 mean & 2.253 & 7.710 & 10.478 & 1.614 \\
$95 \%$ CI & $(1.979-2.527)$ & $(6.882-8.538)$ & $(9.740-11.217)$ & $(1.406-1.822)$ \\
2015 mean & 1.729 & 6.034 & 10.223 & 1.239 \\
$95 \%$ CI & $(1.478-1.979)$ & $(5.269-6.798)$ & $(9.403-11.043)$ & $(1.047-1.430)$ \\
\hline
\end{tabular}

Notes: SOEP v32 (Sample 1), own calculations.

The Sen index and its components are measured in percent.

Confidence intervals are defined as the point estimate plus or minus 1.96 times the standard deviation of the bootstrap-estimator with 200 repetitions. 
Table A.4: Quintiles of the regional-specific hourly wage distribution in 2013

\begin{tabular}{lccccc}
\hline & Q1 & Q2 & Q3 & Q4 & Q5 \\
\hline Sample 1 & & & & & \\
Contractual wages: observations & 2,555 & 2,600 & 2,617 & 2,600 & 2,572 \\
$\quad$ average & 8.23 & 12.84 & 17.46 & 26.28 & 46.38 \\
& & & & & \\
Actual wages: observations & 2,555 & 2,600 & 2,617 & 2,600 & 2,572 \\
$\quad$ average & 7.32 & 11.69 & 15.74 & 21.66 & 38.48 \\
\hline Sample 2 & & & & & \\
Contractual wages: observations & 953 & 1,308 & 1,620 & 1,613 & 471 \\
$\quad$ average & 8.41 & 12.91 & 17.42 & 25.59 & 37.25 \\
& & & & & \\
Actual wages: observations & 1,002 & 1,307 & 1,597 & 1,709 & 1,102 \\
$\quad$ average & 7.35 & 11.65 & 15.70 & 21.62 & 32.92 \\
\hline
\end{tabular}

Notes: SOEP v32 (Sample 1 and Sample 2), own calculations. 
Figure A.1: Pen's parades for contractual gross hourly wages (2013 to 2015), by employment category)

Full-time
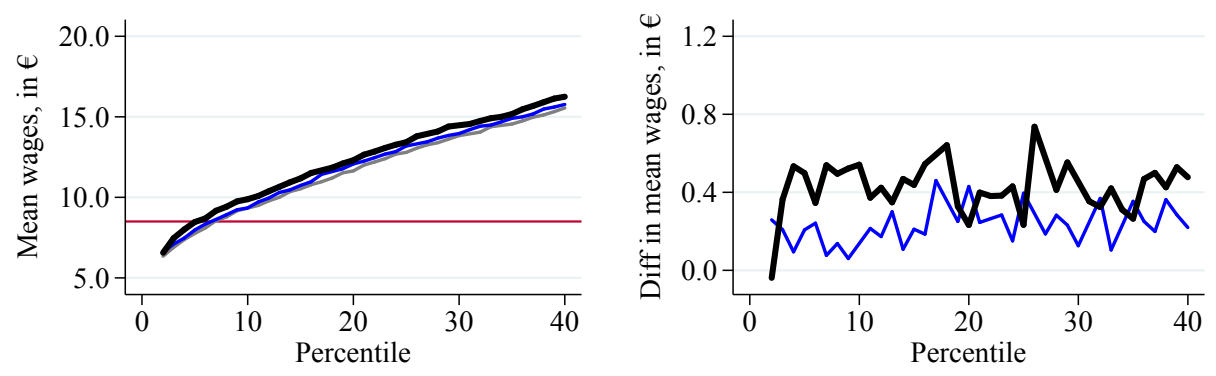

Part-time
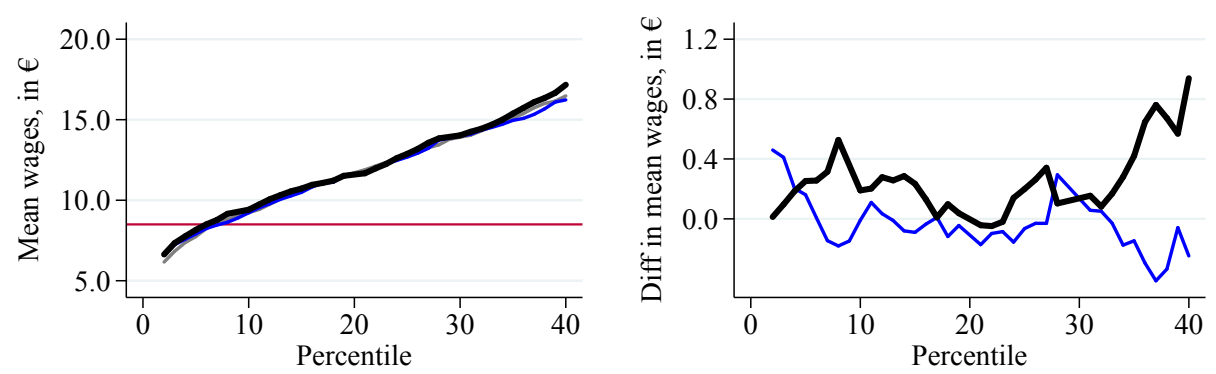

Mini-job
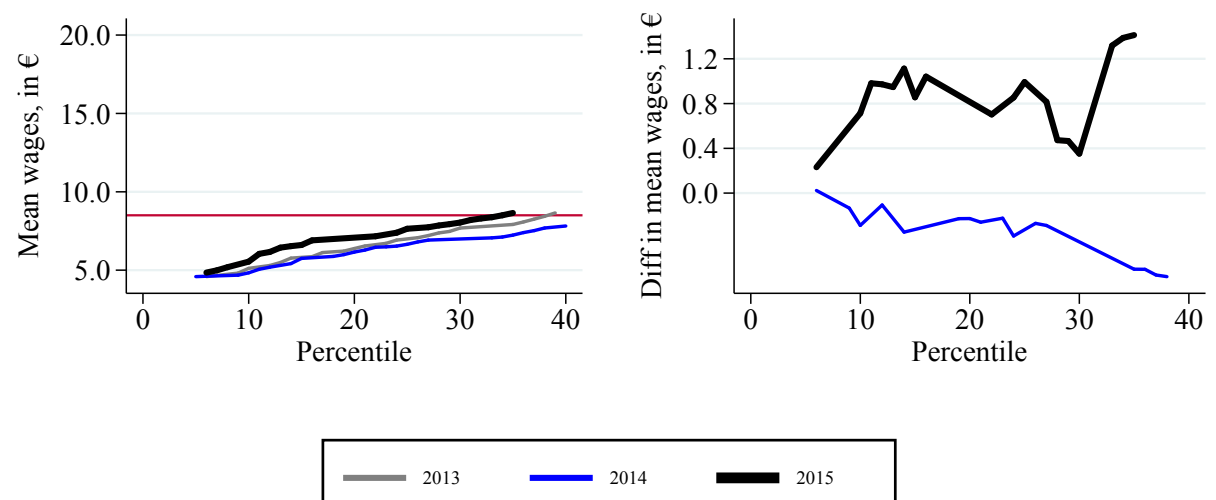

Notes: SOEP v32 (Sample 1), own calculations. Weighted by individual frequency weights. 
Figure A.2: Pen's parades for gross monthly earnings (2013 to 2015) by employment category Full-time
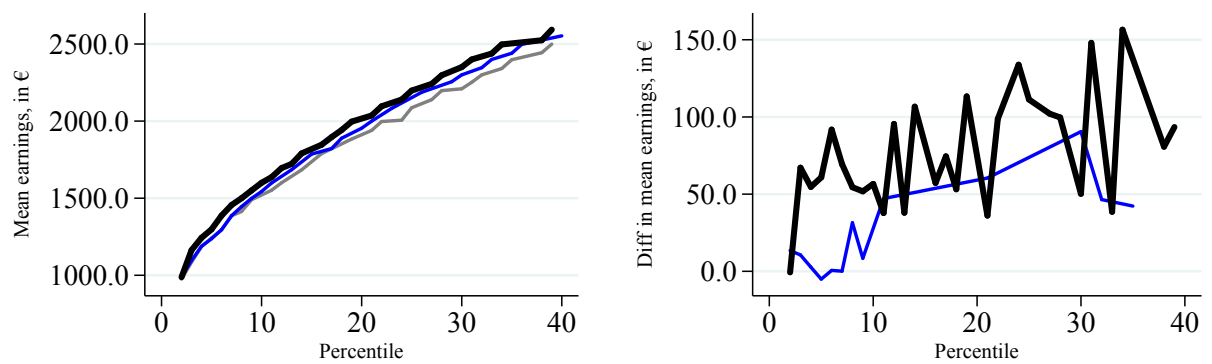

Part-time
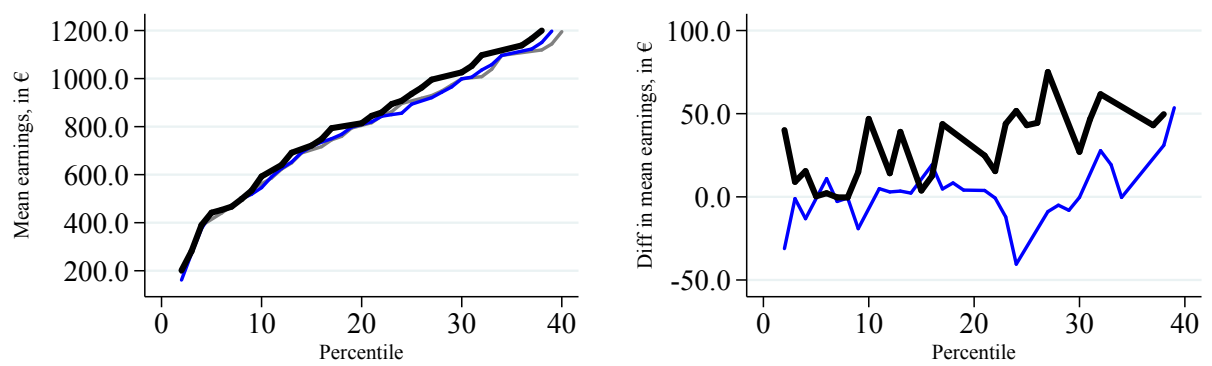

Mini-job
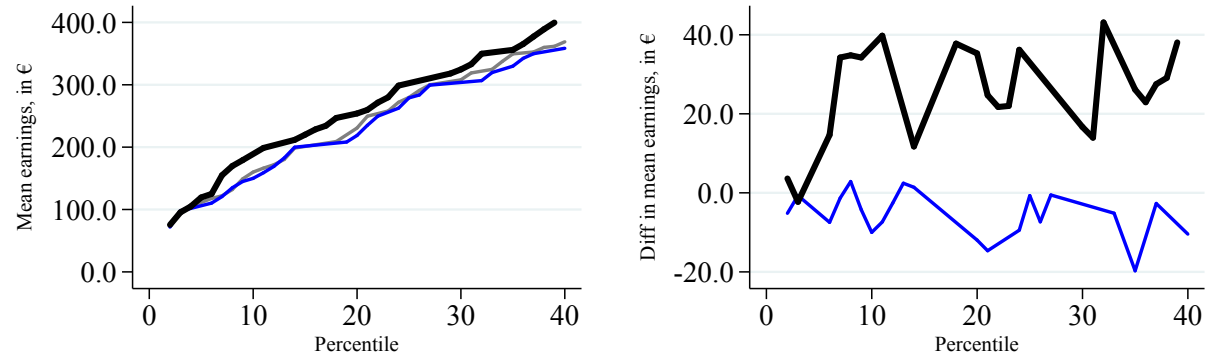

$$
2013 \quad 2014 \quad 2015
$$

Notes: SOEP v32 (Sample 1), own calculations. Weighted by individual frequency weights. 


\section{B Construction of eligibility status from SOEP data}

In order to identify respondents who are eligible for the minimum wage and divide them into sub-groups, we used the rich information from the SOEP questionnaire on current employment as well as employment history and age. Using this information, we derived a (mutually exclusive) labor market status for each respondent. Such a classification is undoubtedly a simplification of the number of possible labor market statuses observed in reality, but it is needed to operationalize the extent to which respondents are affected by the minimum wage reform. The labor market status was defined in several steps; the order is important as it mirrors the assumed dominance of the statuses over each other. As an example, we departed from the non-employment status, which by definition does not need any information from the survey questionnaire (Step 1). Then, in Step 2 we employed survey information that helps to classify a respondent as a full-time employee, and, if all the imposed conditions were binding, the labor market status was updated from non-employed to full-time employment. Further, in Step 12 we employed the information of the currently employed, but with the job that started less than 6 months ago and was preceded by an unemployment spell of more than 12 months. If these conditions were binding, then the labor market status received an additional update to exempt the formerly long-term unemployed.

Step 1: Non-employment. We started by declaring all respondents non-employed. Using additional information from the questionnaire, this status was over-written as follows.

Step 2: Full-time employment with social security. Respondents who fulfilled the following conditions: paid social security contributions (plb0022), not self-employed (plb0059, plb0060, plb0061, plb0062), working more than 30 hours by contract (plb0176, if this information was unavailable, we used actual hours worked plb0186).

Step 3: Part-time employment with social security. Respondents with social security contributions (plb0022), not self-employed, working 30 hours or less by contract (plb0176, if this information was unavailable, we used actual hours worked plb0186), aged 18 and older.

Step 4: Unemployed, not working. Registered unemployed (plb0021) with zero or missing information on wages or hours worked.

Step 5: Unemployed, working. Registered unemployed (plb0021) with either non-zero wages or hours worked.

Step 6: Mini-jobs. Marginally employed (plb0187), not registered as unemployed, and aged over 18 . 
Step 7: Employed in sectors with minimum wages under €8.50. Employed with information on sector of employment and in sectors that have a minimum wage regulation and where minimum wages are set below $€ 8.50$.

Step 8: Employed in sectors with minimum wages at $€ 8.50$ or above. Employed with information on sector of employment and in sectors that have a minimum wage regulation and where minimum wages are set at $€ 8.50$ or higher.

Step 9: Self-employed. Respondents reporting being self-employed with or without employees or being supporting family members (plb0059, plb0060, plb0061, plb0062).

Step 10: Civil servants. Respondents employed as civil servants (plb0065) previously unclassified in other categories.

Step 11: Exempted trainees. Respondents in any type of training or internship (plb0063).

Step 12: Exempted former long-term unemployed. Respondents who started a new job less than 6 months ago (but no earlier than January 1, 2015) and who were unemployed for at least 12 months prior to this job. Here we used both the month of the interview as well as information on the timing of the start of the last job and calendar information on previous unemployment.

Labor market categories Mutually exclusive categories that result from the step-wise application of survey information defined the labor market statuses of the respondents.

Eligibility Categories "Full-time employment with social security," "Part-time employment with social security," "Marginal employment," and "Civil servants" as defined above were used in the analysis as eligible for minimum wages. 